\title{
RADIOMETRIC SURVEYING FOR Th AND U MINERALIZATION IN SOUTHWESTERN, SRI LANKA: RADIOLOGICAL, MINERALOGICAL AND GEOCHEMICAL CHARACTERISTICS OF THE RADIOACTIVE ANOMALIES
}

\author{
K.A.G. SAMEERA ${ }^{1,2^{*}}$, W.A.G.K. WICKRAMASINGHE ${ }^{1,2}$, S.B. HARANKAHAWA ${ }^{1}$, \\ C.R. WELIKANNA ${ }^{1}$, K.T.U.S. DE SILVA ${ }^{1}$ \\ ${ }^{1}$ Geological Survey and Mines Bureau, Sri Lanka \\ ${ }^{2}$ Post Graduate Institute of Science, University of Peradeniya, Sri Lanka \\ *Corresponding Author: e-mail-geethsami2@gmail.com
}

ABSTRACT

(Received $4^{\text {th }}$ January 2020; accepted $16^{\text {th }}$ April 2020)

\begin{abstract}
Radioactive emanations (gamma-ray) from minerals due to the natural decay of radioactive elements (U, $\mathrm{Th}, \mathrm{K}$, etc.), is used as a tool to identify radioactive mineral occurrences. Sri Lanka is famed for occurrences of thorium-bearing minerals. A car-borne gamma-ray spectrometric survey has been initiated by Geological Survey and Mines Bureau (GSMB) to trace promising Th, U mineralization of the country. Herein we report and interpret the radiological, mineralogical, geochemical characteristics, and the possible origin of the radioactive anomalies identified during the survey in southwestern part of Sri Lanka covered by the Aluthgama-Galle geological sheet area. The typical gamma dose rate (GDR) recorded for the study area is $50-80 \mathrm{nSv} / \mathrm{h}$ and the GDR values vary with the local geology. The identified anomalies were categorized into three groups based on the GDR and associated geology as; Group I: 100 - 300 nSv/h, Group II: 300 - 600 nSv/h, and Group III: > 600 nSv/h (Inland and beach/raised beach locations). The highest GDR value of $2300 \mathrm{nSv} / \mathrm{h}(\mathrm{Th}-432 \mathrm{nSv} / \mathrm{h}, \mathrm{U}-141 \mathrm{nSv} / \mathrm{h}$, and $\mathrm{K}-49 \mathrm{nSv} / \mathrm{h})$ is recorded at Uragasmanhandiya. Inland radioactive anomalies of Group III are associated with pegmatite occurrences (e.g. Uragasmanhandiya, Pituwala, Makubura, etc.) with characteristic mineralogy of quartz + feldspar + monazite + zircon \pm biotite \pm garnet \pm ilmenite while higher monazite and zircon contents have been reported for beach/raised beach anomalies. The average Th/U ratio for the Group III anomalies is 32.99, which is higher than the average ratio for the upper crust, indicating the high abundance of Th compared to $\mathrm{U}$ in the terrain. Higher enrichment factors compared to the average upper crust have been reported for high field strength elements especially for Th, La, Ce and Zr (e.g. 28 - 1400 for Th, 5 - 407 for La, 5 - 445 for Ce and 1 - 291 for Zr). The combined analysis of radiology, mineralogy, and geochemistry shows that the radioactive anomalies mainly depend on the monazite content at each locality, and monazite serve as the main source for the high concentration of $\mathrm{Th}, \mathrm{La}$ and Ce. The frequent distribution of radioactive anomalies and occurrences of pegmatites along the shear zones, faults and major lineaments of the terrain suggests a structurally influenced radioactive mineralization. The results of the analysis show that the main source for the monazite placer deposits in the southwestern coastal region is the monazite-rich granitic pegmatites and associated gneisses of the region. A widespread study is suggested to evaluate the $U$, Th, $\mathrm{La}$ and $\mathrm{Ce}$ mineralization in the country in terms of the extent and economic potential.
\end{abstract}

Keywords: Th, U mineralization, radiometric surveying, radioactive anomalies, monazite

\section{INTRODUCTION}

The primary sources of the natural radioactivity in soils and rocks are the occurrence of radionuclides of Uranium $\left({ }^{238} \mathrm{U}\right)$, Thorium $\left({ }^{232} \mathrm{Th}\right)$ series, and Potassium $\left({ }^{40} \mathrm{~K}\right)$ in the earth's crust (Vosniakos et al., 2002; Yasir et al., 2007). The presence of naturally occurring radioactive elements in mineral's composition causes radioactivity in minerals and decaying of radionuclides from such minerals emits alpha, beta and gamma radiation. Although many of the radioactive elements have isotopes, only $\mathrm{U}$, Th decay series and $\mathrm{K}$ isotopes generate measurable energies of gamma rays (IAEA, 2003) and mainly contribute to the terrestrial background 
radiation (Yeboah et al., 2001). During radiometric surveying, radioactive emanations (gamma-ray) from minerals used to detect and map radioactive mineralizations (Haldar, 2013; Killeen et al., 2015). The crustal abundance of long-lived radionuclides such as $\mathrm{U}$ and $\mathrm{Th}$ is very low and their crustal distribution is not homogeneous. The average upper crustal abundance for $\mathrm{U}$ is about 2.8 $\mathrm{ppm}$ and it occurs as three isotopes in nature viz. U-238, U-235, and U-234 (Taylor and McLennan, 1995). On the other hand, Th occurs as a single isotope, Th-232 in nature with an average upper crustal abundance of $10.7 \mathrm{ppm}$ (Taylor and McLennan, 1995). In contrast, $\mathrm{K}$ is more abundant $(2 \%)$ than $\mathrm{U}$ or Th in the crust and mainly found in minerals like mica and feldspar (Dickson and Scott, 1997). However, the average abundance of radioactive elements in mantle and core regions is much less than the crust due to progressive concentration on the crust with time (Dhana Raju, 2005).

In general, radioactive minerals of $U$ and $T h$ occur in diverse igneous, metamorphic and sedimentary rocks, and well-known sources of radioactive deposits are acidic plutonic and volcanic rocks including pegmatites, altered low-grade metamorphic rocks, sedimentary rocks (e.g. sandstone, pyrite bearing conglomerates), phosphatic and carbonaceous rocks (Dhana Raju, 2005). Uranium ions are more soluble in water than thorium, hence it mineralizes in many secondary minerals (e.g. torbernite, and autunite, etc.) in addition to primary minerals such as uraninite. Several types of $\mathrm{U}$ mineralization have been found in Canada, Kazakhstan, Australia and Namibia etc. In contrast to $\mathrm{U}$, Th does not show a uniform distribution in the world, however, granitic and metamorphic rocks found in the Brazil Shield, southern and eastern Africa, Madagascar, southern India, Australia, China, USA and Canada are often enriched in Th relative to the world's average (IAEA, 2019a). Furthermore, placer deposits of Th are found in coastal areas and rivers in India, Australia, Brazil, etc. Significantly, many of the primary and secondary Th deposits are also associated with the major Rare Earth Elements (REE) deposits in the world (IAEA, 2019b).

Sri Lanka is well known for its occurrence of radioactive minerals, especially $\mathrm{Th}$ bearing minerals such as thorianite, thorite, monazite, allanite, ekanite, zircon, fergusonite, zirkelite, xenotime and baddeleyite, etc. (Fletcher, 1893; Coomaraswamy, 1904a, b, 1905, 1906; Dunstan, 1904; Dunstan and Blake, 1905; Wadia and Fernando, 1946; Anderson et al., 1961; Searle, 1962a, b, c; Tennakoon, 2011; Sameera et al., 2020a, b). The history of the radioactive mineral survey in Sri Lanka dates back to the early $20^{\text {th }}$ century. After the discovery of thorianite by Ananda Coomaraswamy (1903), mineral surveys on radioactive minerals were broadened and some occurrences of thorianite and thorite such as at Maddegama, Bambarabotuwa, We-Ganga, etc. have been reported (Coomaraswamy, 1904a, 1904b, 1905, 1906). Then, mineral surveys were focused on occurrences of monazite which consist of REE in addition to thorium, especially in the beach and river sand deposits. Several radioactive mineral surveys in Sri Lanka were conducted by the predecessors of the Geological Survey and Mines Bureau (GSMB) in its history including, monazite survey along coastal regions (1910), an airborne radiometric survey covering the coastal strip from Puttalam to Tangalla (1957), a car-borne gamma-ray spectrometer survey (1962), surveys on uranium mineralization (1979) which identified significant occurrences of radioactive mineral deposits (Abeysinghe, 1985; Abeysinghe and Fernando, 1986; Jayawardane, 1986). In recent times, GSMB has initiated an island-wide nuclear raw material survey (IWNRMS) using a car-borne gamma-ray spectrometer to trace promising $\mathrm{Th}, \mathrm{U}$ mineralization of the country.

Previous radiometric surveys on radioactive mineral occurrences ( $\mathrm{Th}$, $\mathrm{U}$ bearing) in the southwestern of Sri Lanka were largely concerted to the coastal zone (Searle, 1962a, c, 1963; Rupasinghe et al., 1983) and data on inland areas are still lack. Hence, under the IWNRMS project, the car-borne gamma-ray radiometric survey has been conducted covering the areas of Aluthgama - Galle geological sheet (No. 19 of the provincial geological map series of the GSMB). Herein we report the identified anomalous radioactive zones and possible radioactive mineral reserves. Moreover, the study interprets the radiological, mineralogical, geochemical characteristics, and the possible geological origin of the identified radioactive anomalies. 


\section{GEOLOGICAL SETTING AND STUDY AREA}

Nine-tenths of the geological basement of Sri Lanka consists of Precambrian metamorphic rocks and the rest is represented by Mesozoic (Jurassic), Tertiary (Miocene) and Quaternary sedimentary formations, and a few occurrences of intrusive igneous rocks. The high-grade metamorphic basement is subdivided into three major units viz. the Highland Complex (HC), the Wanni Complex (WC), and the Vijayan Complex (VC) (Kröner et al., 1991; Cooray, 1994) (Figure 1).

Geologically, the studied area is underlain by highly deformed Proterozoic metamorphic rocks in the southwestern part of the $\mathrm{HC}$ and crustal residence age of the $\mathrm{HC}$ is varying within 2 - 3 Ga (Milisenda et al., 1988; Kroner et al., 1991). However, the southwestern region of the $\mathrm{HC}$ shows a notable lithological difference compared to the rock units of HC. The lesser occurrence of major quartzite and marble bands and the presence of wollastonite bearing calc-silicate rocks in this particular part of the HC compared to the rest of the HC are a significant feature in the sense of lithology (Prame and Pohl, 1994) (Figure 1). Additionally, rocks of the southwestern region have experienced a relatively low pressure (5 6 kbar) metamorphism compared to the rocks in the rest of the HC (Faulhaber and Raith, 1991).

Major lithological units encountered within the area of interest are charnockites, charnockitic gneisses, and garnetiferous quartzo-feldspathic rocks. Wollastonite and scapolite bearing calcgneisses (Hapuarachchi, 1969; Sameera and Perera, 2015) and mappable bands or lenses of cordierite bearing pelitic gneisses also occur within the area (Figure 1). Towards the northeastern edge of the area, amphibolites, hornblende, and pyroxene rich rocks are interlayered with minor metasediments and charnockities. Several post-metamorphic intrusives are distributed within the study area and the main intrusive formation encountered is medium to coarse-grained hornblende granite exposed at the Arangala area (Cooray, 1965). Relatively lesser, but similar granites are exposed at Imaduwa and Ukwatta area. Other notable intrusives are hypersthene granite occurring at Halkandawila, quartz- feldspar, pegmatites, quartz veins, and several small dolerite dikes (Cooray, 1965). Several quaternary deposits such as beach rocks, unconsolidated sand, and laterite are found along the coastal belt of the Galle district (Figure 1). Beach rock (littoral sandstone) occurs at Kaikawala and Koggala and unconsolidated sands occur around Beruwala, Bentota, and Ambalangoda. Besides, some inland sand deposits are found around Aluthgama, Kosgoda, and Uragaha area. Most of the laterite formations developed in situ over the crystalline basement with thicknesses of 1 or 2 meters with the extension of several meters. They are well exposed around Beruwala, Payagala, Matugama and Balapitiya area.

\section{METHODOLOGY}

\section{Field Survey}

Field surveys to obtain the radiological data were carried out primarily using a car-borne gamma-ray spectrometer (MONA) which is equipped with combined highly sensitive fourliter $\mathrm{NaI}$ (doped with $\mathrm{Tl}$ ) detector and a highresolution $2 \times 2 \mathrm{LaBr}_{3}$ (doped with $\mathrm{Ce}$ ) detector. The detector is positioned inside a hermitical casing and uses a photomultiplier as a light sensor for the light emission by the scintillator crystal. The instrument is manufactured by ENVINET GmbH, Germany for the primary use of monitoring environmental radiation. Since the GSMB possessed two of the MONA detectors, during the field survey, the regular use of the instrument was modified to identify radioactive anomalous zones and mineral deposits associated with natural terrestrial radioactive isotopes ( $\mathrm{Th}, \mathrm{U}$ and $\mathrm{K}$ ). The scintillation detector of the MONA records ambient gamma dose equivalent rate $\dot{\mathrm{H}}^{*}(10)$ (simply used as Gamma Dose Rate - GDR in the paper) in $\mathrm{nSv} / \mathrm{h}$ and nuclide specific gamma dose rate such as nuclides of Th, $\mathrm{U}, \mathrm{K}$, Y, I, Cs, etc. Every reachable road track of the Aluthgama - Galle geology sheet were surveyed using the MONA instrument which was mounted at a height of about $2 \mathrm{~m}$ from the ground. The instrument records data at onesecond intervals while moving at an average speed of $25 \mathrm{~km} / \mathrm{h}$ and it displays real-time with a color code assigned to the radiation value of the surrounding. 


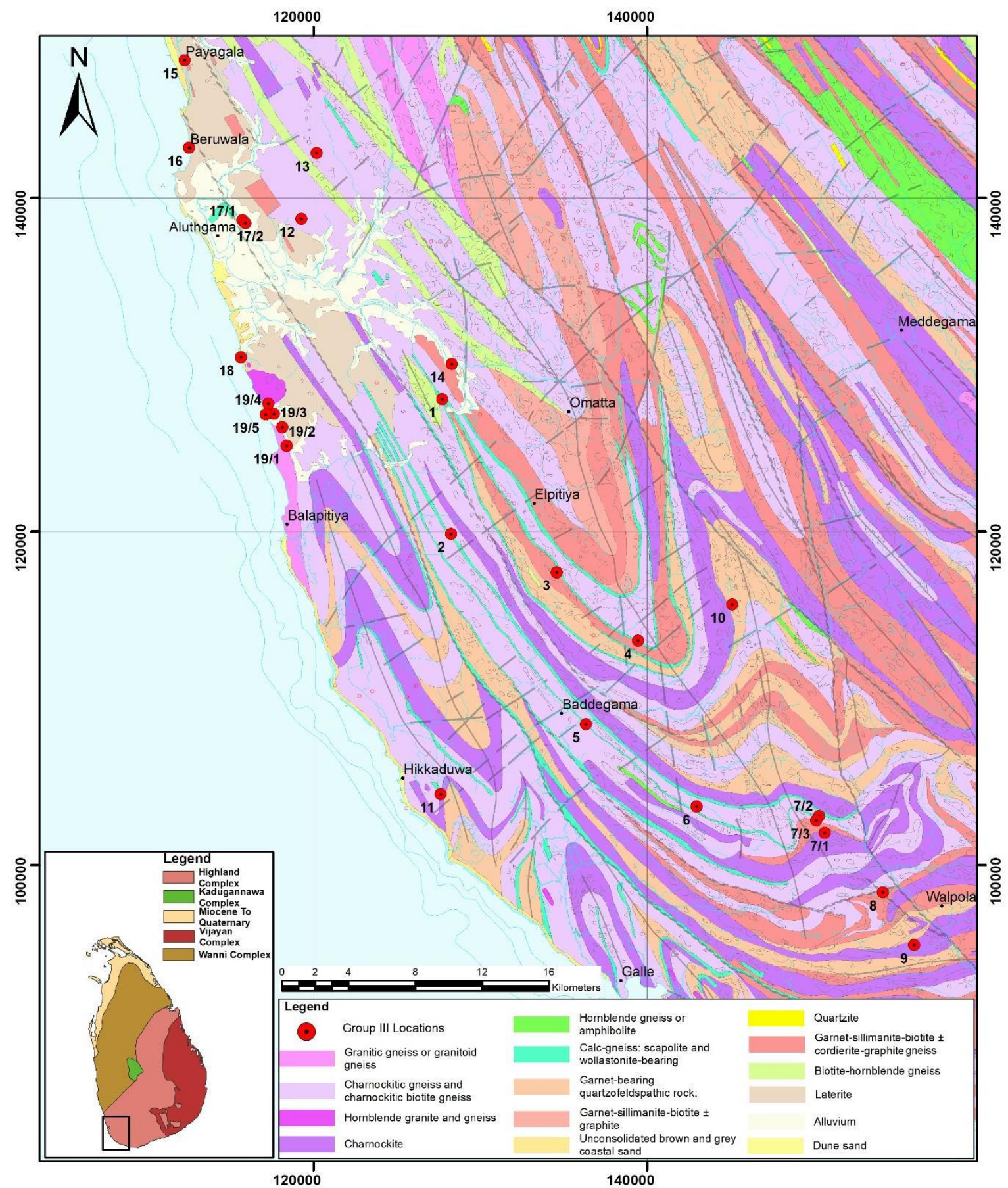

Fig. 1. Lithotectonic subdivision of the Precambrian of Sri Lanka (after Cooray, 1994) showing study area; Aluthgama - Galle geological sheet (1:100000) area and identified radioactive anomalous zones in Group III.

During the survey, special attention was given to the topographical and geometrical factors, soil conditions, overburden thickness, and other geological aspects of the particular area. After detecting an anomalous radiation value in a specific area, the area is then surveyed using a portable gamma-ray spectrometer with a grid system to determine the distribution pattern of the anomaly within the area. The portable gamma-ray instrument used during the survey was RS 125. It contains a high sensitivity performance $6.3 \mathrm{Cu}$ ins $\mathrm{NaI}$ detector and is capable of measuring count rate data in counts/sec continuously, and measures $\mathrm{K}$ as a percentage (\%), $\mathrm{U}$ and $\mathrm{Th}$ as equivalent concentrations (eU and $\mathrm{eTh}$ ) in ppm during the assaying. The precision of the data estimated to be the square root of the value based on counting statistics and on numerous replicate analyses (Killeen and Cameron, 1977; Lentz, 
1991). These data were gathered on the ground surface (flat surfaces) with the assay time of about five minutes. Both instruments were calibrated using international standard samples before starting the survey.

\section{Sampling and Mineralogical/ Geochemical Analysis}

A representative sample of soil, sand, or rock from each site which records the highest count rate in the selected anomalous areas was collected for detailed laboratory analysis. A representative portion of each sample was divided into $>2000 \mu \mathrm{m}, 2000-1000 \mu \mathrm{m}, 1000$ - $63 \mu \mathrm{m}$ size fractions through wet sieving, oven drying and dry sieving, and grain size between $63 \mu \mathrm{m}$ to $1000 \mu \mathrm{m}$ has been selected for further separations. Depending on the samples, heavy liquid separation using sodium polytungstate (S.G. 2.86) was conducted to separate heavy mineral fraction from lighter fractions. Then, to separate the heavy mineral fraction into seven different sub-fractions, the isodynamic magnetic separator was used by changing the amperage and side slope angle. Mineral grains from each fraction (including lighter fraction and $>2000 \mu \mathrm{m} / 2000-1000$ $\mu \mathrm{m}$ fractions) were mounted on glass slides and all the minerals found on the slides were systematically studied under the stereomicroscope. Further clarification of the minerals was done using refractive index liquids and petrographic microscopes. Finally, grain counting was done considering the grain shape/size, and each mineral's weight percentages were determined. Chemical analysis of major and trace elements of the selected samples was conducted using a BRUKER S8 TIGER WD-XRF instrument at the GSMB analytical laboratory. Pressed pellets were prepared by mixing $9 \mathrm{~g}$ of powdered representative samples from each selected location with $2.7 \mathrm{~g}$ of paraffin binder and compressed under a pressure of $15 \mathrm{t}$, before the analysis. XRF instrument was calibrated for major and trace elements using standard samples and locally prepared standards.

\section{RESULTS}

Mainly, three types of data were acquired for the interpretations of the study, including radiological, mineralogical and geochemical data of the collected samples from selected radioactive anomalies. The results are described separately in the following sections.

\section{Radiological Data and Field Relations}

To measure the GDR and to identify the radioactive anomalies, the car-borne gammaray spectrometer survey was conducted. A number of 108 different traverses were made to cover the whole study area. The average background GDR values for the area varied between $50-80 \mathrm{nSv} / \mathrm{h}$ and the average nuclide specific background GDR values for $\mathrm{Th}$, U and $\mathrm{K}$ were recorded as $6 \mathrm{nSv} / \mathrm{h}, 5 \mathrm{nSv} / \mathrm{h}$ and 3 $\mathrm{nSv} / \mathrm{h}$ respectively with minor variations. According to the measurements, recorded GDR values for swampy or paddy areas (25 $40 \mathrm{nSv} / \mathrm{h}$ ) were lower than the average background GDR and in contrast, measured average GDR values for quartz-rich beach areas were even lower $(10-20 \mathrm{nSv} / \mathrm{h})$. The recorded GDR for the terrains consisting of charnockitic rocks was $50-60 \mathrm{nSv} / \mathrm{h}$ whereas GDR of 70 - $80 \mathrm{nSv} / \mathrm{h}$ was recorded for garnet-bearing or quartzofeldspathic gneissic terrains. Considering the recorded GDR values for different terrains, a base GDR value of 100 $\mathrm{nSv} / \mathrm{h}$ was assigned to describe the radioactive anomalies of the study area. For systematic analyzing and interpreting purposes, three subgroups of anomalies (areas) were categorized based on the reported GDR values and the associated geological features of a particular area.

Group I: Locations with GDR values $100-300 \mathrm{nSv} / \mathrm{h}$

Group II: Locations with GDR values $300-600 \mathrm{nSv} / \mathrm{h}$

Group III: Locations with GDR values above $600 \mathrm{nSv} / \mathrm{h}$

A number of localities were identified under Group I anomalies and fifty-two areas were recognized under Group II. Special attention was given for the Group III anomalies which consist of the highest GDR values within the study area. Nineteen anomalous areas were identified under Group III and they were further categorized into inland and beach/ raised beach locations considering their occurrences (Table 1), (Figure 1). 
Table 1. Radiological data of the identified radioactive anomalous zones in Group III.

\begin{tabular}{|c|c|c|c|c|c|c|c|c|c|}
\hline \multirow{3}{*}{$\begin{array}{l}\text { Location } \\
\text { No. }\end{array}$} & \multirow{3}{*}{ Location } & \multicolumn{4}{|c|}{ Car-borne Gamma Ray Spectrometer Data } & \multicolumn{4}{|c|}{ Portable Gamma Ray Spectrometer Data } \\
\hline & & \multicolumn{3}{|c|}{ Nuclide Specific Gamma Dose Rate (nSv/h) } & \multirow{2}{*}{$\begin{array}{c}\text { GDR value } \\
\text { (nSv/h) }\end{array}$} & \multirow{2}{*}{$\begin{array}{c}\text { Highest Count } \\
\text { Rate (counts/sec) }\end{array}$} & \multirow{2}{*}{$\begin{array}{c}\text { eTh } \\
\text { (ppm) }\end{array}$} & \multirow{2}{*}{$\begin{array}{c}\mathrm{eU} \\
(\mathbf{p p m})\end{array}$} & \multirow{2}{*}{$\begin{array}{c}\mathbf{K} \\
(\%)\end{array}$} \\
\hline & & Th & $\mathbf{U}$ & $\mathbf{K}$ & & & & & \\
\hline L1 & Uragasmanhandiya & 432 & 142 & 49 & 2320 & 15500 & 4095 & 70 & 10.4 \\
\hline $\mathrm{L} 2$ & Kurudugahahetekma & 100 & 76 & 7 & 1020 & 16500 & 1765 & 689 & 8.7 \\
\hline L3 & Pituwala & 190 & 77 & 11 & 1020 & 11750 & 2424 & 38 & 5.7 \\
\hline L4 & Idigahawila & 209 & 45 & 16 & 1320 & 21000 & 4411 & 211 & 7.5 \\
\hline L5 & Baddegama & 124 & 41 & 11 & 800 & 14000 & 4102 & 83 & 1.4 \\
\hline L6 & Wanduraba & 59 & 42 & 14 & 696 & 3500 & 551 & 21 & 3.2 \\
\hline $\mathrm{L} 7 / 1$ & & 149 & 51 & 17 & 884 & 18000 & 4214 & 147 & 10.2 \\
\hline $\mathrm{L} 7 / 2$ & Makubura & 103 & 33 & 13 & 666 & 10410 & 2223 & 63 & 2.8 \\
\hline $\mathrm{L} 7 / 3$ & & 114 & 50 & 16 & 781 & 6430 & 1150 & 43 & 2.4 \\
\hline L8 & Yakkalamulla & 162 & 46 & 27 & 857 & 12200 & 1932 & 38 & 8.5 \\
\hline L9 & Hiyare & 123 & 45 & 13 & 772 & 14200 & 2617 & 81 & 6.5 \\
\hline L10 & Mapalagama & 148 & 50 & 13 & 772 & 8500 & 1858 & 52 & 3.7 \\
\hline L11 & Hikkaduwa & 110 & 33 & 16 & 625 & 4200 & 642 & 24 & 2.8 \\
\hline L12 & Pinnaduwa & 95 & 26 & 10 & 601 & 3000 & 410 & 10 & 1.2 \\
\hline L13 & Annasigala & - & - & 13 & 604 & 3500 & 439 & 11 & 2.5 \\
\hline L14 & Maha-Uragaha & 104 & 26 & 3 & 631 & 7200 & 1441 & 44 & 1.1 \\
\hline L15 & Payagala & 103 & 32 & 9 & 728 & 13500 & 2493 & 185 & 0.0 \\
\hline L16 & Beruwala & 192 & 63 & 9 & 1130 & 31600 & $>10000$ & 778 & 0.0 \\
\hline L17/1 & & 124 & 44 & 6 & 786 & 4500 & 743 & 58 & 0.0 \\
\hline $\mathrm{L} 17 / 2$ & Dharga town & 146 & 52 & 6 & 914 & 7500 & 1612 & 91 & 0.1 \\
\hline L18 & Kaikawala & 158 & 108 & 7 & 1600 & 13720 & 3381 & 195 & 0.2 \\
\hline L19/1 & & 102 & 79 & 9 & 1440 & 10300 & 1920 & 190 & 0.2 \\
\hline L19/2 & & 216 & 51 & 9 & 1410 & 10180 & 1887 & 187 & 0.0 \\
\hline L19/3 & Kosgoda & 288 & 93 & 5 & 1720 & 17000 & 3518 & 276 & 0.1 \\
\hline L19/4 & & 255 & 78 & 6 & 1580 & 11700 & 2489 & 226 & 0.1 \\
\hline L19/5 & & 103 & 37 & 7 & 607 & 4600 & 715 & 55 & 0.0 \\
\hline
\end{tabular}



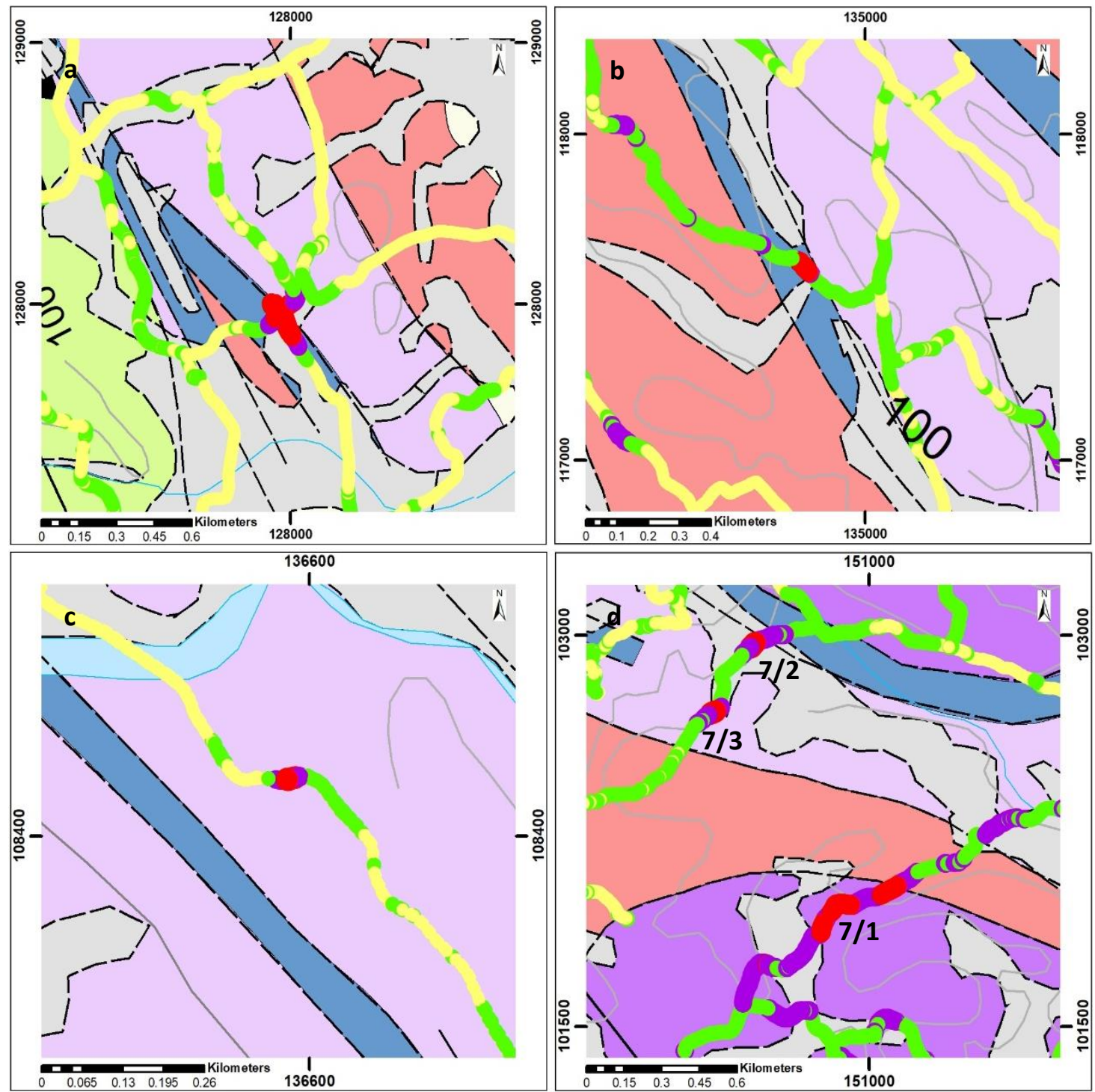

Legend

Geology

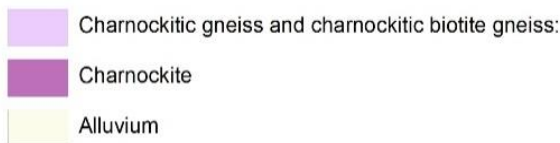

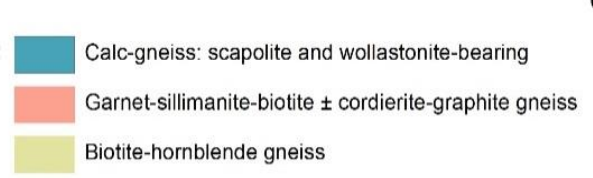

GDR value (nSv/h)

() $0-100$

$101-300$

$301-600$

$>601$

Fig. 2. Car-borne gamma ray spectrometer road traverses showing anomalous GDR values of inland locations in Group III at (a) L01, (b) L03, (c) L05, (d) L07 on Aluthgama - Galle geological map (sheet no. 19).

\section{Inland Locations}

These locations were located distant from the coast and/or were not associated with beach heavy mineral sand occurrences. These particular locations were analyzed in detail due to the possibility of being the sources for radioactive minerals including monazite which is found in the beaches/ raised beach locations. Fourteen inland anomalies were identified under Group III within the study area and four noteworthy anomalies are described here.

\section{Uragasmanhandiya (L01)}

This inland location is surrounded by relatively flat topography and the area is covered with paddy and cinnamon plantations. Small outcrops of quartzofeldspathic gneisses, charnockite and calc-gneisses are exposed at the site. Anomalous GDR values were distributed along two minor roads which run through the area (about $200 \mathrm{~m}$ and $150 \mathrm{~m}$ sections of the roads) (Figure 2a). The highest 
recorded GDR value for the site was 2320 $\mathrm{nSv} / \mathrm{h}$ (around 40 times greater than the normal background GDR) with nuclide specific dose rates of Th - $432 \mathrm{nSv} / \mathrm{h}, \mathrm{U}-141$ $\mathrm{nSv} / \mathrm{h}$ and $\mathrm{K}-49 \mathrm{nSv} / \mathrm{h}$ (Table 1). The location possessed the highest nuclide specific dose rate of $\mathrm{Th}, \mathrm{U}$ for the entire study area. The anomalous area was examined using the portable gamma-ray spectrometer and the highest count rate recorded was 15,500 counts/sec (Table 1). A weathered pegmatite underlain by a $0.5 \mathrm{~m}$ thick soil cover was identified close to the location (Figure 3a) and the common mineral phases of the area identified are slightly weathered feldspar, biotite mica and fresh quartz.

\section{Pituwala (L03)}

This area is characterized by ridge and valley topography and covered with paddy, tea and cinnamon plantations. Three mutually separated anomalous GDR sites were identified along the minor village roads which run through the Pituwala area (Figure 2b) and the highest recorded GDR value was 1020 $\mathrm{nSv} / \mathrm{h}$ (18 times greater than the normal background) with $\mathrm{Th}-190 \mathrm{nSv} / \mathrm{h}, \mathrm{U}-76$ $\mathrm{nSv} / \mathrm{h}$ and $\mathrm{K}-10 \mathrm{nSv} / \mathrm{h}$ of nuclide specific dose rates (Table 1). The major anomaly extends for about $300 \mathrm{~m}$ along a road and the second anomaly was identified along the same road. The third anomaly was recorded $1 \mathrm{~km}$ southwest of the first two locations (Figure 2b). The measured GDR for second and third locations varies within $400-600 \mathrm{nSv} / \mathrm{h}$. The major anomaly was examined using the portable gamma-ray spectrometer and count rate of 11,750 counts/sec with eTh - 2,424 ppm, eU - 38 ppm was recorded at the highly weathered pegmatite vein. Within the proximity of the anomaly, a fresh pegmatite outcrop was observed with ilmenite, monazite, magnetite, quartz, feldspar and biotite mica (Figure $3 b$ ). Monazite grains are up to $4 \mathrm{~mm}$ size and mainly associated with ilmenite + magnetite rich areas within the outcrop. The particular outcrop shows a higher GDR value and $3000-4000$ counts/sec count rate was recorded on its surface. Also, along the slope of the ridges, fresh outcrops and rock boulders of pegmatites, garnet granulites, and calcgneisses are observed.

\section{Baddegama (LO5)}

This inland location shows a slightly rising ridge and valley topography which is composed of paddy and tea cultivations. The anomaly was recorded along a minor road within the area and it extends nearly for about $100 \mathrm{~m}$ (Figure 2c). The highest GDR value recorded at the site was $800 \mathrm{nSv} / \mathrm{h}$ (14 times greater than the normal background) with $\mathrm{Th}$ $124 \mathrm{nSv} / \mathrm{h}, \mathrm{U}-40 \mathrm{nSv} / \mathrm{h}$ and $\mathrm{K}-11 \mathrm{nSv} / \mathrm{h}$ (Table 1). The area was further surveyed with the portable gamma-ray spectrometer and the highest measured count rate was 14,000 counts/sec with eTh - 4102 ppm, eU - 82.9 ppm for a separated rock fragment (Table 1). This area is entirely different from other localities and is characterized by the presence of heavy, dark coloured rock fragments (up to $0.2 \mathrm{~m}$ sizes) and the origin of them is still ambiguous (secondary origin?) (Figure 3c). The rock pieces were scattered within the top of the soil cover on a small ridge. A gem gravel layer was also identified at top of the same ridge with round or nearly round quartz pebbles associated with lateritic soil. However, there were no signs of occurrence of a pegmatite vein and/or country rock in the area.

\section{Makubura (LO7)}

The area is composed of ridge and valley topography and mostly covered with tea, cinnamon and paddy lands. Three main radioactive anomalous locations were encountered within the Makubura area. The first anomalous site extends for about $1.5 \mathrm{~km}$ and the highest recorded GDR value was 884 $\mathrm{nSv} / \mathrm{h}$ (15 times greater than the normal background) with individual dose rates of Th $148 \mathrm{nSv} / \mathrm{h}, \mathrm{U}-51 \mathrm{nSv} / \mathrm{h}$ and $\mathrm{K}-16 \mathrm{nSv} / \mathrm{h}$ (Figure 2d) (Table 1). The second anomalous site was located $1 \mathrm{~km}$ away towards the northern side of the first and extends to about $150 \mathrm{~m}$ along a minor road. The highest recorded GDR value for the particular site was $781 \mathrm{nSv} / \mathrm{h}$ with nuclide specific dose rates of $\mathrm{Th}-113 \mathrm{nSv} / \mathrm{h}, \mathrm{U}-50 \mathrm{nSv} / \mathrm{h}$, and $\mathrm{K}-13$ $\mathrm{nSv} / \mathrm{h}$ (Table 1). The third anomalous site is located $200 \mathrm{~m}$ from the second along the same road and extends up to $100 \mathrm{~m}$. The highest reported GDR value for the site was 666 $\mathrm{nSv} / \mathrm{h}$. 

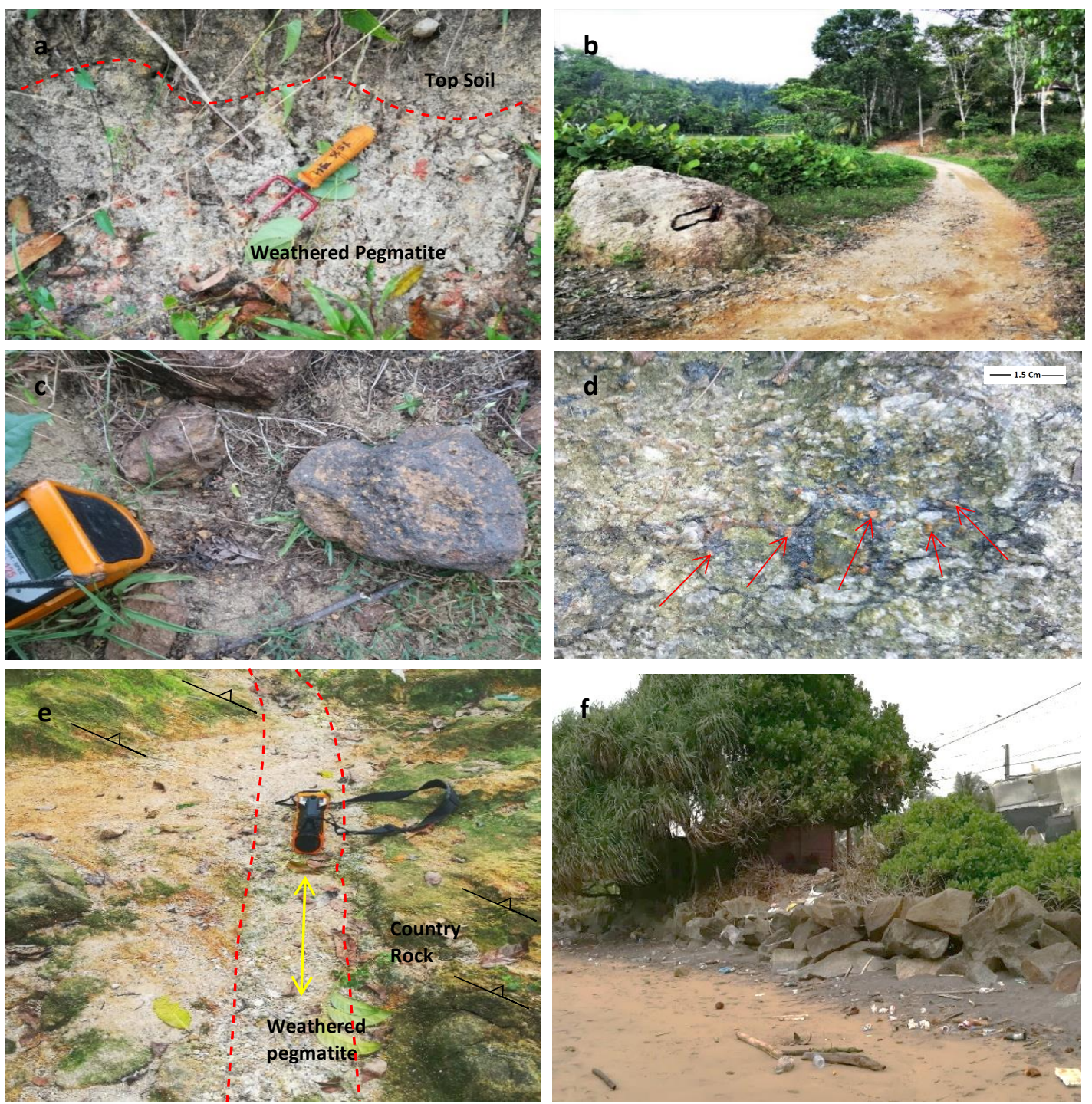

Fig. 3. Field photographs of the radioactive anomalous zones in Group III, (a) a weathered pegmatite layer exposed beneath the top soil cover at a road cut in LO1, (b) radioactive anomalous area at L03 consisting fresh pegmatitic outcrop, (c) a black colour, hard, radioactive, secondary originated rock sample at L05, (d) monazite grains (red arrows) associated with ilmenite rich areas in quartz + feldspar pegmatite at LOT, (e) a radioactive mineral consisting, weathered pegmatite dyke cross-cutting a weathered garnet-bearing gneissic rock at LO7, (f) radioactive minerals consisting, heavy minerals rich sand occurrence at the beach in L16.

The whole area was then surveyed using the portable gamma-ray spectrometer. The measured highest count rate was 18,000 counts/sec for the area and it was recorded at a slightly weathered pegmatite vein (eTh - 4214 ppm, eU - $147 \mathrm{ppm})$. The two feet wide pegmatite vein consisting of biotite mica, smoky quartz and feldspar cross-cuts the weathered garnet-bearing gneissic country rock (Figure $3 e)$. Also, in the surrounding area, several relatively large outcrops and boulders $(10 \times 15$ m) of pegmatites with quartz + feldspar + garnet + monazite \pm ilmenite \pm biotite were identified.
Monazite (up to $6 \mathrm{~mm}$ in size) are mainly associated with garnet and/or ilmenite rich patches within the outcrops (Figure 3d). In addition, some associated gneisses within the area also showed anomalous radioactivity. The area is also characterized by the presence of gem minerals including well-developed crystals of quartz, zircon, tourmaline, and occurrences of chrysoberyl and ekanite. Moreover, boulders/ outcrops of garnet-bearing gneisses, quartzofeldspathic gneisses, charnockites, and calc-gneisses are observed during traversing through the roads within the area. 

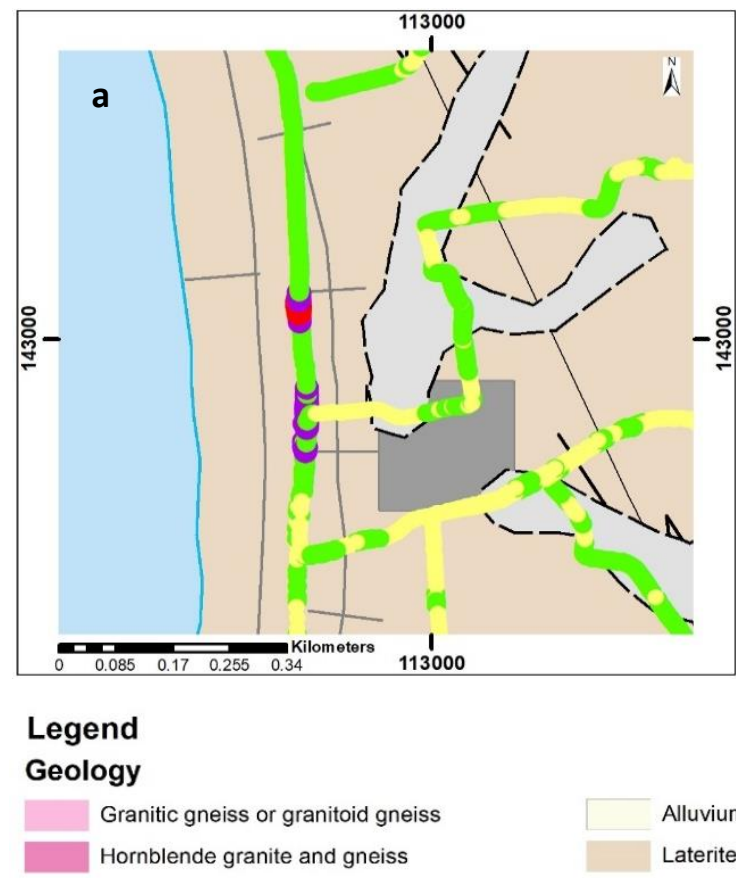
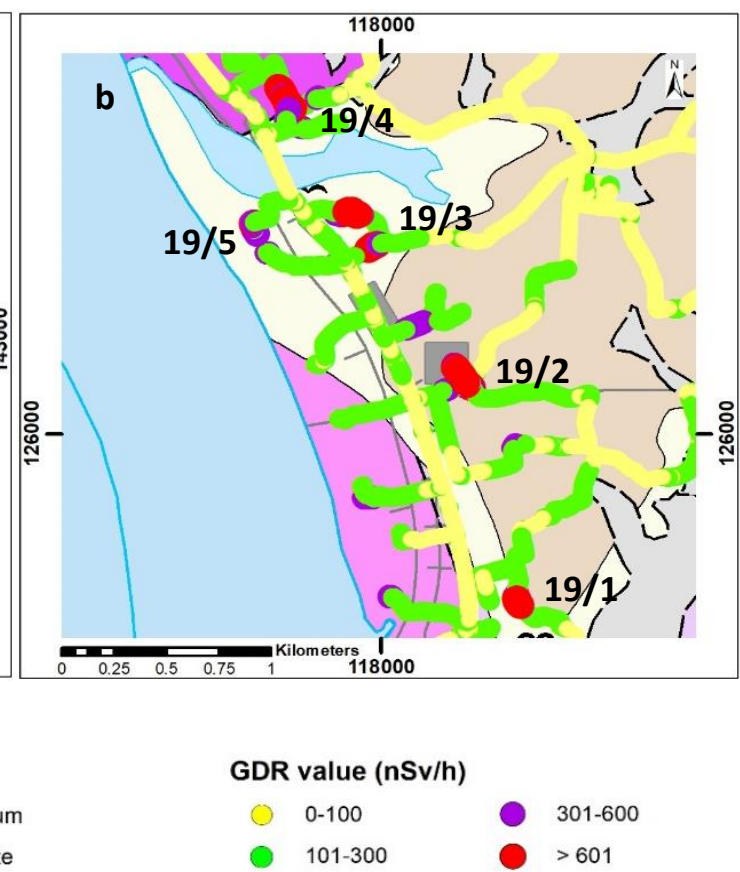

Fig. 4. Car-borne gamma-ray spectrometer road traverses showing anomalous GDR values of the beach and raised beach locations in Group III at (a) L16, (b) L19 on Aluthgama - Galle geological map (sheet no. 19).

Further, field evidences of pegmatite occurrences were observed at many of the inland anomalous locations, e.g. L04, L06, L08, L11 and L14. The highest eU was recorded at L02 within the study area (Table 1). In addition, several notable inland areas with anomalous GDR values of 200 - 600 $\mathrm{nSv} / \mathrm{h}$ within Group I and II were identified, e.g. Bulugaha-Omatta, Maddegama-Neluwa, Matugama area, etc. Even though the Maddegama area was previously reported as a thorianite bearing locality (Hood, 1959), the recorded GDR during the survey was between $150-300 \mathrm{nSv} / \mathrm{h}$. However, several abandoned thorianite mined pits were observed and traces of pegmatitic veins were identified within the area. It is a well-known location for the occurrence of gem species viz. chrysoberyl, alexandrite, zircon and tourmaline.

\section{Beach and Raised Beaches}

Beach anomalies are located close to the present-day coastline whereas raised beaches are positioned several meters away from the beach $(100 \mathrm{~m}$ to $1 \mathrm{~km})$, towards the inland. Most of these types of radioactive mineralbearing zones were confined to the coastal stretch from Payagala to Balapitiya (Figure 1) and characterized by the presence of ilmenite rich black sands. Five anomalous areas identified within the study area and two of the important anomalies are described here.

\section{Beruwala (L16)}

This location is situated in Beruwala beach, 12 $\mathrm{km}$ north of the Aluthgama town. The width of the beach area is about $20-25 \mathrm{~m}$ and most of the area is covered with black sands. Anomalous GDR values were recorded while traversing parallel to the beach along the Colombo - Galle main road (A2) (Figure 4a). The highest GDR value recorded for the area was $1,130 \mathrm{nSv} / \mathrm{h}$ (20 times greater than the normal background) (Table 01) whereas the portable gamma-ray spectrometer recorded 31,600 counts/sec (79 times greater than the background) with eTh - > $10000 \mathrm{ppm}, \mathrm{eU}$ $778.4 \mathrm{ppm}$ (Table 1). This was the highest recorded count rate by the instrument for the entire study area as well as the highest Th and $\mathrm{U}$ equivalent concentration. The area was rich in ilmenite dominated black sands and quartz was almost absent in some areas (Figure 3f).

\section{Kosgoda (L19)}

The location is situated in the Kosgoda area, $10 \mathrm{~km}$ south of the Aluthgama town. The area 
shows flat topography and most of the land has been used for cultivation purposes and is relatively populated. Four adjoined raised beach areas (L19/1, L19/2, L19/3, L19/4) and one beach location (L19/5) were identified as anomalies based on GDR values (Figure 4b). Most of the raised beach locations were situated about 200 - $500 \mathrm{~m}$ away from the present coastline. Anomalous GDR values were reported along a minor village road. The highest GDR values, nuclide specific dose rates of $\mathrm{Th}, \mathrm{U}$, and $\mathrm{K}$ recorded at each locality are given in Table 1 . The area was surveyed using the portable gamma-ray spectrometer and the highest counts rate was reported as 17,000 counts/sec for L19/3 with eTh - 3,518 ppm and eU - $276 \mathrm{ppm}$. All of these locations were rich in ilmenite/rutile rich black sands and were occasionally associated with lateritic overburden. The black sand layer extended to 5 to $10 \mathrm{~m}$ depth in some areas.

\section{Mineralogical Analysis}

Both mineralogical composition and physical properties of the minerals such as grain shape and color of the samples from inland locations and, beach/raised beaches show a significant variance between the two groups of samples and occasionally between the samples of own group as described below.

\section{Inland Soil/Rock Samples}

The characteristic mineral observed in these samples is monazite and it occurs as a minor mineral in most of the samples (Table 2). In contrast, monazite was also encountered as a major mineral in secondary rock pieces at Baddegama (L05). Yellow-colored monazite grains were encountered mainly in the medium sand size $(0.25-0.5 \mathrm{~mm})$ and occasionally in coarse sand size $(0.5-1 \mathrm{~mm})$ (Figure 5a). Monazite grains show an anhedral to subhedral shape and occasionally occur as euhedral well developed prismatic to wedgeshaped crystals (Figure 5a, b). They are transparent to translucent and show resinous to vitreous luster (Figure 5a, b). Zircon grains occur in all of the samples as minor or trace minerals with well-developed tetragonal prismatic crystal shapes. Zircon in inland samples are light purple and rarely observed as colorless crystals (Figure 5c). They are of fine sand size $(0.125-0.25 \mathrm{~mm})$ to medium sand size and occasionally occur as coarse sand to gravel size grains (Figure 5c). Quartz is usually medium to coarse sand size with vitreous luster and always occurs as the major mineral except at the L05 (Table 2). Feldspar content is higher in inland samples and is of medium to coarse sand size with anhedral to subhedral shapes. Another distinctive mineral group observed within the inland samples is limonite, and it mainly occurs as a minor mineral except in samples 01, 07 and 08 . They are brown to reddish-brown and occur as medium to coarse sand. Garnets are coarse to medium sand size and are brownish-red in color. However, they occur as trace amounts or even absent in most of the inland samples except in sample 10 (Table 2). Moreover, ilmenite and rutile occur as trace amounts except in a few samples (Table 2). Mica is mainly of biotite and shows the black color flaky appearance and comprises a higher amount in weathered pegmatites at L03, L07.

\section{Beach/Raised Beach Sand Samples}

Many of the beach samples are rich in ilmenite and rutile and show characteristic black color. The grain size distribution of most of the samples shows a similar pattern and varies between medium to fine sand size. Monazite is the distinctive mineral of all samples and observed as a minor mineral. The highest monazite percentage is recorded for sand samples from the Beruwala beach (Table 2). Compared to the inland samples, monazite in beach and raised beaches show a well-rounded shape and are of fine to very fine sand-size grains (Figure 5d). Zircon is also found as a minor mineral in all of the samples and the highest concentration is reported for the Beruwala beach sands (L16). All of them are fine to very fine sand size and have retained their tetragonal crystal structure despite being transported long distances before deposition (Figure 5e). The colour of the zircon grains from beach samples is almost colorless and shows a characteristic difference to zircon from the inland samples which are light purple (Figure 5e). Black color ilmenite grains of fine to medium sand size exhibit angular to subrounded grain shapes (Figure 5f). They occur as a major mineral along with quartz in many of the samples (Table 2). Garnet grains are brownish-red to pink in color and occur as a minor mineral in most of the samples (Figure 
5f) (Table 2). They are angular in shape and show vitreous luster. Spinel shows various colors, i.e. colorless, green, purple and blue and, most of them exhibit subrounded shapes with sporadical euhedral octahedral crystals. Rutile is a minor mineral found in most of the samples and are euhedral (tetragonal crystals) in shape with its characteristic luster. Most of the sillimanite grains are elongated and
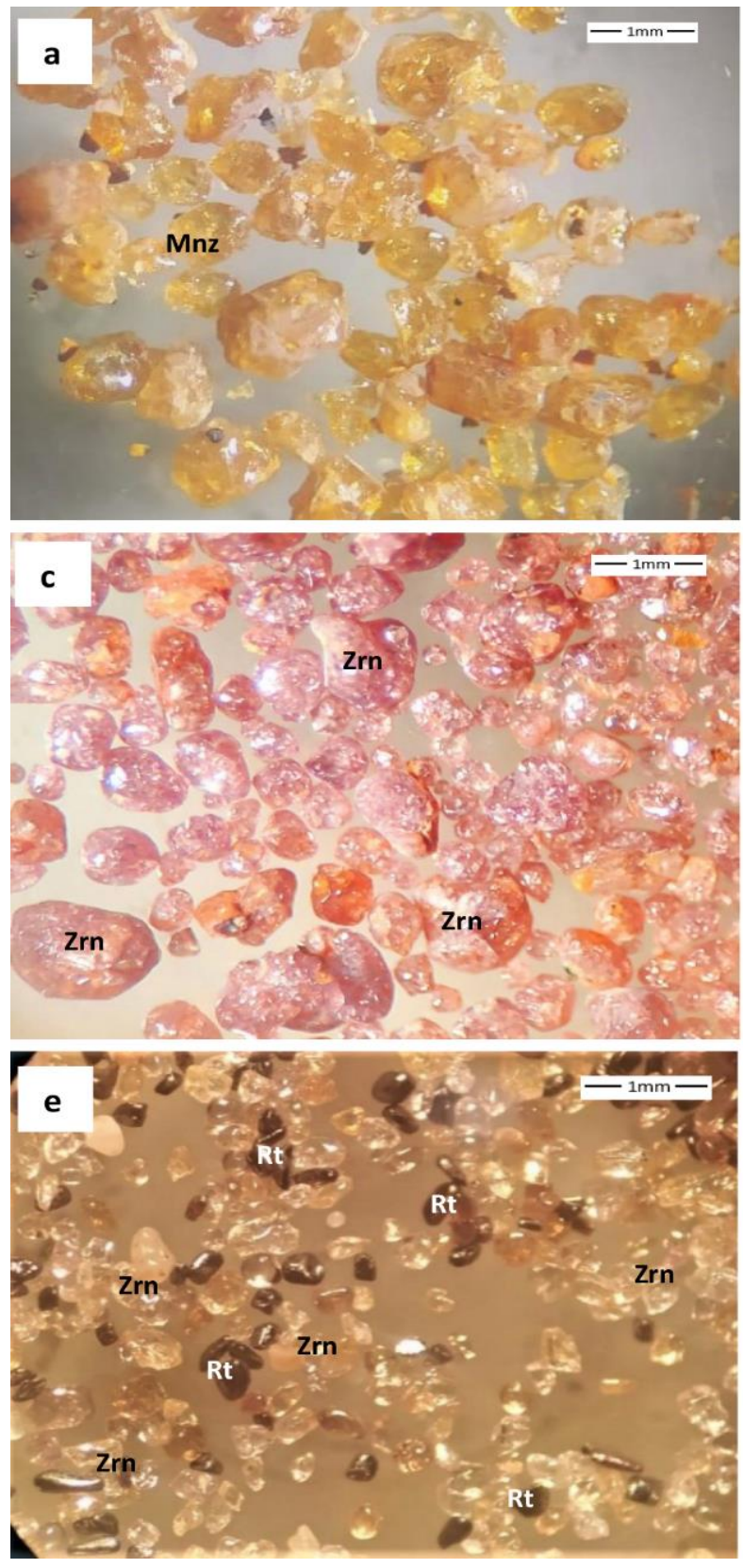

colorless and its quantity is higher in beach and raised beach samples compared to inland samples (Table 2). The significant difference between the beach/raised beach to the inland samples is the presence of low limonite and feldspar content and higher ilmenite and rutile. Furthermore, all of the samples show a lesser amount of hornblende compared to other beach sand occurrences in Sri Lanka.
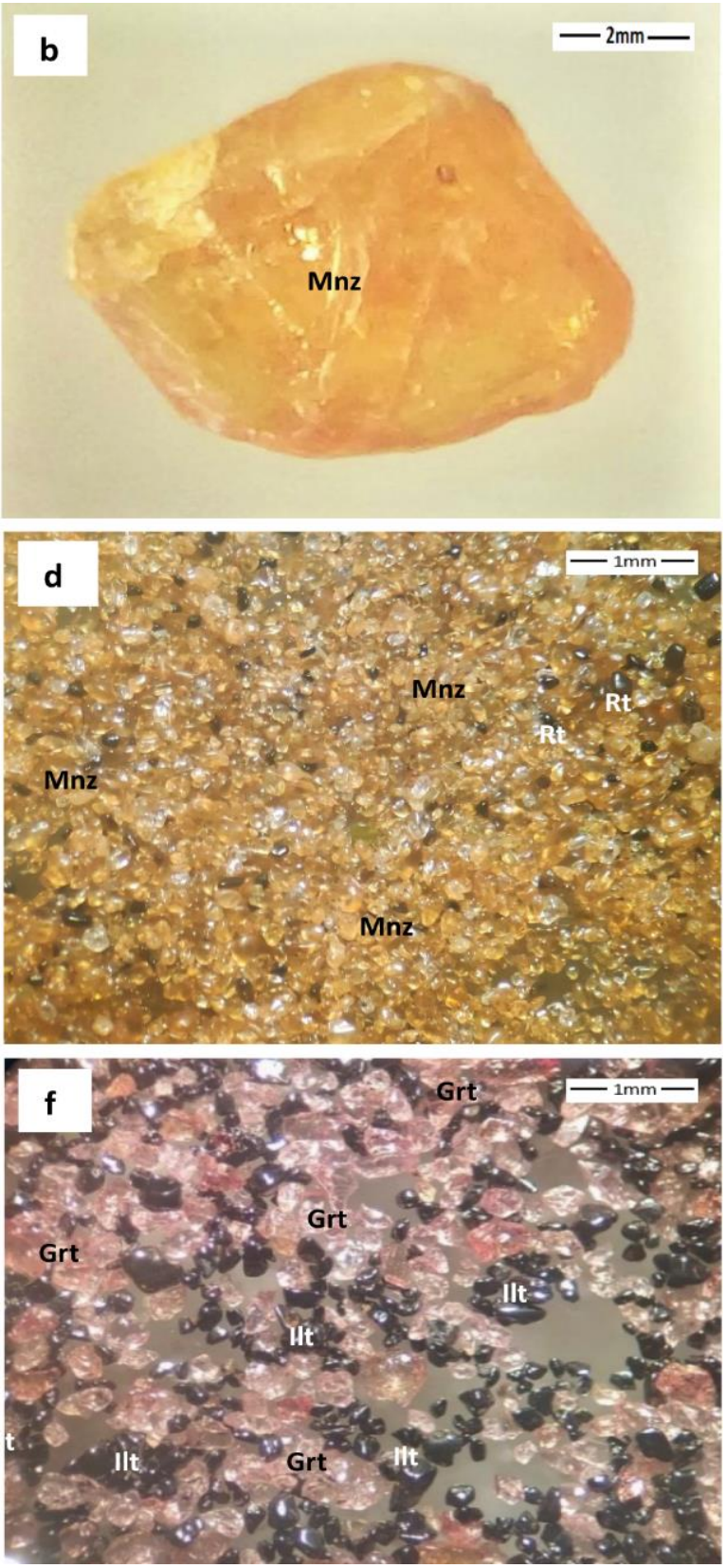

Fig. 5. Photomicrographs of minerals in inland and beach/raised beach samples of Group III under reflected light view of a stereo microscope, (a) angular, subhedral to anhedral monazite grains at L07, (b) a wedgeshaped euhedral monazite crystal at L07, (c) purplish colour, euhedral tetragonal prismatic zircon grains at L03, (d) rounded to subrounded fine-grained monazite grains at L16, (e) colourless subrounded to euhedral/tetragonal zircon grains and needle-like brownish-black rutile grains at L16, $(f)$ reddish-pink colour angular garnet grains and subrounded black ilmenite grains at L19 (Mnz-monazite, Zrn - zircon, Rt-rutile, Ilt-ilmenite, Grt-garnet). 
Table 2. Mineralogical compositions of some of the samples from radioactive anomalous zones in Group III.

\begin{tabular}{|c|c|c|c|c|c|c|c|c|c|c|c|c|c|c|c|c|c|}
\hline \multirow{3}{*}{ Mineral } & \multicolumn{17}{|c|}{ Weight Percentages (\%) } \\
\hline & \multicolumn{10}{|c|}{ Inland locations } & \multicolumn{7}{|c|}{ Beach and raised beach locations } \\
\hline & L01 & L02 & $\mathbf{L 0 3}$ & L04 & L05 & L06 & L07 & L08 & L09 & L10 & L15 & L16 & $\mathbf{L 1 7 / 2}$ & L18 & $\mathbf{L} 19 / 2$ & $\mathbf{L 1 9 / 3}$ & L19/4 \\
\hline Biotite & - & - & 10.83 & - & - & - & 29.45 & - & 0.10 & 0.73 & 0.05 & - & - & - & - & - & - \\
\hline Feldspar & 3.46 & 0.47 & 24.72 & 4.76 & - & 8.89 & 37.14 & 7.59 & 4.41 & 4.41 & 0.28 & - & 0.23 & - & 0.12 & 0.22 & 0.23 \\
\hline Garnet & - & - & - & 0.03 & - & 0.12 & - & - & - & 12.13 & 3.70 & 8.50 & 6.80 & 1.37 & 2.55 & 6.91 & 6.79 \\
\hline Hornblende & - & - & - & - & - & - & - & - & - & - & - & - & - & - & 0.03 & 0.10 & - \\
\hline Hypersthene & - & - & - & - & - & - & - & - & - & - & - & 0.04 & - & 0.19 & - & - & - \\
\hline Ilmenite & 3.92 & 2.90 & 4.76 & 0.27 & 59.03 & 2.06 & 0.16 & 0.29 & 2.94 & 11.96 & 40.05 & 56.43 & 35.45 & 25.58 & 49.80 & 41.01 & 35.41 \\
\hline Leucoxene & - & - & 0.12 & 0.02 & - & 0.07 & - & 0.74 & 0.18 & 0.65 & 1.30 & 1.61 & 1.26 & 0.73 & 1.08 & 1.43 & 1.26 \\
\hline Limonite & 0.11 & 16.07 & 9.47 & 16.59 & 4.78 & 11.26 & 0.72 & 25.56 & 6.25 & 4.08 & 0.65 & - & 0.68 & - & 0.92 & 0.18 & 0.68 \\
\hline Magnetite & - & - & - & - & - & - & - & - & - & - & 0.01 & - & - & - & - & - & - \\
\hline Monazite & 5.57 & 0.22 & 10.60 & 10.20 & 24.78 & 0.57 & 15.57 & 8.47 & 5.80 & 9.95 & 4.12 & 12.20 & 8.67 & 6.25 & 2.29 & 6.75 & 8.77 \\
\hline Pyroxene & - & - & - & - & - & - & - & - & - & - & 0.06 & - & - & - & - & - & - \\
\hline Quartz & 86.12 & 78.14 & 29.24 & 67.57 & 1.53 & 76.13 & 16.01 & 53.26 & 76.32 & 54.00 & 36.47 & 0.28 & 20.75 & 16.56 & 23.90 & 22.08 & 20.50 \\
\hline Rutile & 0.19 & 0.45 & 0.01 & - & 0.10 & 0.26 & - & 0.10 & 0.56 & 0.29 & 3.45 & 6.43 & 13.00 & 5.22 & 7.61 & 7.90 & 12.99 \\
\hline Sillimanite & - & 0.13 & - & - & - & 0.10 & - & - & 1.68 & 0.05 & 2.73 & 1.08 & 2.89 & 1.27 & 1.39 & 1.69 & 2.89 \\
\hline Spinel & - & - & - & - & - & - & - & - & - & - & - & 1.61 & 1.15 & 1.49 & 1.31 & 0.83 & 1.15 \\
\hline Zircon & 0.22 & 0.24 & 9.75 & 0.10 & 7.76 & 0.35 & 0.64 & 3.55 & 1.16 & 0.75 & 6.41 & 11.05 & 8.29 & 4.72 & 8.38 & 10.26 & 8.28 \\
\hline Graphite & - & 0.60 & - & - & - & - & - & - & - & 0.43 & - & - & - & - & - & - & - \\
\hline Shell & - & - & - & - & - & - & - & - & - & - & 0.05 & 0.30 & - & 35.86 & - & - & - \\
\hline Others & 0.30 & 0.28 & 0.40 & 0.43 & 0.92 & 0.15 & 0.11 & 0.20 & 0.22 & 0.24 & 0.56 & 0.68 & 0.52 & 0.66 & 0.54 & 0.48 & 0.62 \\
\hline Total & 99.90 & 99.50 & 99.91 & 99.98 & 98.90 & 99.98 & 99.80 & 99.76 & 99.63 & 99.66 & 99.90 & 99.65 & 99.70 & 99.89 & 99.93 & 99.84 & 99.57 \\
\hline
\end{tabular}




\section{Geochemistry}

The major and trace element concentration of inland and beach/raised beach samples exhibit various patterns under different elemental groups viz. alkali and alkali earth elements, transition group elements, High Field Strength Elements (HFSE), etc. Alkali and alkali earth elements ( $\mathrm{Na}, \mathrm{K}, \mathrm{Mg}, \mathrm{Ca}, \mathrm{Rb}, \mathrm{Sr}, \mathrm{Ba}$ ) show dissimilar variations between the two groups of samples. Although the concentration of this particular group of elements is low in both types of samples, the concentration of $\mathrm{K}$ shows a higher value in inland soil samples than the beach/raised beach samples (Table 3). The highest concentration of $\mathrm{Mg}, \mathrm{K}, \mathrm{Rb}$ and $\mathrm{Ba}$ is recorded for the weathered pegmatite samples from the Makubura area (Table 3 and 4). Even though the $\mathrm{Ca}$ and $\mathrm{Sr}$ concentration is low in many of the locations, the highest value for $\mathrm{Ca}$ and $\mathrm{Sr}$ is recorded from the Kaikawala beach samples since it is rich in carbonate materials (Table 2, 3 and 4). The concentration of some of the transition group elements ( Ti, V, Cr, Mn, Fe, Co, Ni, Cu, Zn) shows a significant variation among the samples of inland and beach/raised beach. Fe always occurs as a major element in the samples and it shows relatively higher weight percentages in the beach/raised beach samples compared to the inland samples. The highest values of $\mathrm{Fe}$ are found in the locations of L05 and L16 (Table 3). Higher Ti content is recorded for the beach/raised beach samples than to the samples from inland locations except at Baddegama (L05) (Table 3). The highest amount of $\mathrm{Mn}, \mathrm{Cu}, \mathrm{Ni}$ is also recorded for L05 location and the highest concentration of $\mathrm{V}, \mathrm{Cr}, \mathrm{Co}, \mathrm{Zn}$ is recorded for $\mathrm{L} 16, \mathrm{~L} 02$, L01, and L19/2 locations respectively (Table 4). The variation of the measured HFSE (Y, $\mathrm{Zr}, \mathrm{Nb}, \mathrm{La}, \mathrm{Ce}, \mathrm{Th}, \mathrm{U})$ concentrations of both inland and beach/raised beach samples show a similar distribution between the elements. According to the data, $\mathrm{Zr}$ is highly concentrated in the beach/raised beach sand samples than the inland locations except for the rock fragments from Baddegama (L05). Th is concentrated in both inland and beach/raised beach locations, and the highest values are recorded at L05 and L16 (Table 4). Moreover, a relatively higher concentration of $\mathrm{Th}$ is recorded for weathered pegmatite samples at L01, L03, L07, and L08. The concentration of $\mathrm{U}$ is always lower than the Th (Table 4) and the average $\mathrm{Th} / \mathrm{U}$ ratio for inland samples is 44.54 and that of the beach/raised beach samples is 21.59. Measured Light Rare Earth Elements (LREE) concentrations, especially of La and $\mathrm{Ce}$, exhibit higher abundance in many of the locations. The highest values of $\mathrm{La}$ and $\mathrm{Ce}$ are recorded for the rock fragments from Baddegama, and Beruwala beach sands (Table 4). Similarly, samples from major pegmatites also recorded elevated values for $\mathrm{La}$ and $\mathrm{Ce}$ (e.g:- at L01, L07, L08). Pb shows a similar abundance pattern as the $\mathrm{Th}$ in all of the samples. The other group of elements (Al, P, $\mathrm{Si}$, and As) also shows a dissimilar abundance pattern between the inland and beach/ raised beach samples. $\mathrm{Si}$ is the most abundant element of all, and the concentration of $\mathrm{Al}$ is relatively higher in inland soil/rock samples than beach samples. Elevated $\mathrm{P}$ content is recorded for beach sand samples at L16, inland rock fragments at L05 and a soil sample at L01 (Table 4).

\section{DISCUSSION}

The results of the radiometric survey, including both car-borne spectrometric and portable gamma-ray spectrometric survey, have shown the occurrence of radioactive anomalous zones, some with promising radioactive mineralization in the area belonging to Aluthgama - Galle geological sheet in southwestern Sri Lanka. These occurrences are further confirmed by the mineralogical and geochemical analysis. Many of the anomalous zones extend along the northwest to the southeast stretch of the map (Figure 1).

The variation of GDR value with the local lithology in the inland areas indicates that the natural radioactivity of a particular area is influenced by the bedrock type and its mineralogy. Most of the inland anomalies are associated with garnet-bearing or quartzofeldspathic gneissic rocks and lesser GDR values were recorded for the terrains consisting of charnockitic rocks. This particular linkage between GDR values and local lithology is excessively revealed by the reported radioactive anomalies belongs to Group I locations, e.g. Matugama, Omatta - Katandola, etc. During weathering, these radionuclides in soils will enrich two to three times greater than the parent rocks (Dickson and Scott, 1997). 
Table 3. Contents of the major elements in the selected radioactive anomalous zones in Group III.

\begin{tabular}{|c|c|c|c|c|c|c|c|c|c|c|c|}
\hline & \multirow{2}{*}{ Location No. } & \multicolumn{10}{|c|}{ Major Elements (in Oxide Wt \%) } \\
\hline & & $\mathrm{TiO}_{2}$ & $\mathrm{Al}_{2} \mathrm{O}_{3}$ & MnO & $\mathrm{MgO}$ & $\mathrm{CaO}$ & $\mathrm{Na}_{2} \mathrm{O}$ & $\mathrm{K}_{2} \mathrm{O}$ & $\mathbf{P}_{2} \mathbf{O}_{5}$ & $\mathrm{Fe}_{2} \mathrm{O}_{3}$ & $\mathrm{SiO}_{2}$ \\
\hline \multirow{10}{*}{ Inland } & L01 & 3.36 & 7.96 & 0.02 & 0.2 & 0.11 & 0.01 & 0.15 & 1.29 & 12.16 & 73.74 \\
\hline & L02 & 1.50 & 28.18 & 0.01 & 0.08 & 0.13 & 0.01 & 0.41 & 0.11 & 19.05 & 50.52 \\
\hline & L03 & 2.43 & 24.33 & 0.01 & 0.93 & 0.07 & 0.14 & 2.91 & 0.19 & 7.28 & 61.71 \\
\hline & L04 & 0.72 & 28.67 & 0.01 & 0.01 & 0.08 & 0.01 & 0.26 & 0.25 & 3.20 & 66.81 \\
\hline & L05 & 14.85 & 2.87 & 0.08 & 0.17 & 0.19 & 0.11 & 0.04 & 3.01 & 52.98 & 17.68 \\
\hline & L06 & 0.92 & 25.42 & 0.02 & 0.02 & 0.08 & 0.01 & 0.33 & 0.11 & 6.84 & 66.26 \\
\hline & L07/1 & 1.71 & 24.65 & 0.02 & 3.01 & 0.08 & 0.19 & 5.00 & 0.55 & 8.30 & 55.49 \\
\hline & L08 & 2.00 & 17.40 & 0.02 & 0.08 & 0.13 & 0.02 & 0.55 & 0.26 & 12.20 & 67.34 \\
\hline & L09 & 2.09 & 15.41 & 0.01 & 0.02 & 0.13 & 0.01 & 0.2 & 0.37 & 10.02 & 71.77 \\
\hline & L10 & 8.22 & 10.35 & 0.04 & 0.20 & 0.24 & 0.05 & 0.78 & 0.56 & 11.26 & 68.30 \\
\hline \multirow{6}{*}{$\begin{array}{l}\text { Beach } \\
\text { and } \\
\text { Raised } \\
\text { Beach }\end{array}$} & L15 & 21.27 & 13.07 & 0.07 & 0.43 & 0.31 & 0.08 & 0.39 & 0.46 & 25.89 & 35.63 \\
\hline & L16 & 30.02 & 8.20 & 0.10 & 1.59 & 2.70 & 0.05 & 0.04 & 3.69 & 44.03 & 2.22 \\
\hline & $\mathrm{L} 17 / 2$ & 18.89 & 11.06 & 0.06 & 0.81 & 1.00 & 0.27 & 0.62 & 0.29 & 19.73 & 45.07 \\
\hline & L18 & 13.32 & 2.72 & 0.02 & 1.81 & 34.57 & 0.22 & 0.27 & 1.16 & 13.07 & 28.64 \\
\hline & L19/2 & 18.94 & 14.39 & 0.06 & 0.36 & 0.35 & 0.27 & 0.71 & 0.45 & 23.58 & 38.99 \\
\hline & $\begin{array}{l}\mathrm{L} 19 / 3 \\
\mathrm{~L} 19 / 4\end{array}$ & $\begin{array}{l}11.78 \\
16.28\end{array}$ & $\begin{array}{l}15.85 \\
14.03\end{array}$ & $\begin{array}{l}0.05 \\
0.06\end{array}$ & $\begin{array}{l}0.38 \\
0.47\end{array}$ & $\begin{array}{l}0.38 \\
0.29\end{array}$ & $\begin{array}{l}0.13 \\
0.06\end{array}$ & $\begin{array}{l}1.00 \\
0.51\end{array}$ & $\begin{array}{l}0.40 \\
0.54\end{array}$ & $\begin{array}{l}18.18 \\
21.47\end{array}$ & $\begin{array}{l}49.95 \\
43.59\end{array}$ \\
\hline
\end{tabular}


Table 4. Trace elements concentrations of the selected radioactive anomalous zones in Group III.

\begin{tabular}{|c|c|c|c|c|c|c|c|c|c|c|c|c|c|c|c|c|c|c|c|c|c|}
\hline \multirow{2}{*}{\multicolumn{2}{|c|}{ Location No. }} & \multicolumn{19}{|c|}{ Trace Elements (ppm) } & \multirow[t]{2}{*}{ Th/U } \\
\hline & & $\mathbf{V}$ & $\mathrm{Cr}$ & Co & $\mathbf{N i}$ & $\mathbf{C u}$ & Zn & Ga & As & $\mathbf{R b}$ & $\mathbf{S r}$ & $\mathbf{Y}$ & $\mathbf{Z r}$ & $\mathbf{N b}$ & $\mathbf{B a}$ & La & $\mathrm{Ce}$ & $\mathbf{P b}$ & Th & $\mathbf{U}$ & \\
\hline \multirow{10}{*}{ Inland } & L01 & 202 & 117 & 45 & 25 & 12 & 10 & 13 & 13 & 5 & 7 & 101 & 6855 & 86 & 2 & 5554 & 12970 & 211 & 6320 & 97 & 65.15 \\
\hline & L02 & 270 & 541 & 0 & 22 & 10 & 34 & 41 & 48 & 18 & 55 & 14 & 841 & 36 & 223 & 164 & 344 & 58 & 294 & 33 & 8.91 \\
\hline & L03 & 97 & 14 & 32 & 45 & 75 & 34 & 28 & 8 & 103 & 74 & 30 & 4847 & 65 & 728 & 1425 & 3540 & 151 & 2278 & 41 & 55.56 \\
\hline & L04 & 61 & 59 & 34 & 17 & 9 & 36 & 35 & 2 & 7 & 3 & 46 & 241 & 14 & 11 & 1807 & 4259 & 107 & 3002 & 57 & 52.67 \\
\hline & L05 & 435 & 82 & 10 & 98 & 75 & 204 & 98 & 3 & 4 & 4 & 586 & 14632 & 358 & 2 & 16519 & 35944 & 854 & 24365 & 778 & 31.32 \\
\hline & L06 & 82 & 88 & 24 & 35 & 21 & 39 & 29 & 120 & 3 & 7 & 24 & 600 & 26 & 45 & 500 & 1261 & 82 & 782 & 21 & 37.24 \\
\hline & L07/1 & 71 & 12 & 31 & 32 & 22 & 184 & 32 & 2 & 333 & 67 & 133 & 1266 & 47 & 884 & 5208 & 10790 & 336 & 6701 & 154 & 43.51 \\
\hline & L08 & 131 & 151 & 14 & 29 & 16 & 54 & 22 & 9 & 2 & 13 & 71 & 1900 & 70 & 74 & 1375 & 3047 & 105 & 1546 & 41 & 37.71 \\
\hline & L09 & 133 & 146 & 35 & 40 & 25 & 38 & 21 & 16 & 5 & 4 & 85 & 3185 & 72 & 38 & 2503 & 5467 & 150 & 3535 & 81 & 43.64 \\
\hline & L10 & 410 & 152 & 19 & 40 & 33 & 164 & 23 & 27 & 3 & 62 & 100 & 17773 & 418 & 194 & 2493 & 6104 & 196 & 4677 & 136 & 34.39 \\
\hline \multirow{7}{*}{$\begin{array}{l}\text { Beach } \\
\text { and } \\
\text { Raised } \\
\text { Beach }\end{array}$} & L15 & 680 & 275 & 38 & 35 & 38 & 198 & 14 & 20 & 3 & 16 & 71 & 21774 & 475 & 2 & 2606 & 5620 & 143 & 2217 & 99 & 22.39 \\
\hline & L16 & 883 & 241 & 8 & 48 & 69 & 220 & 4 & 40 & 7 & 174 & 427 & 69133 & 1133 & 2 & 9646 & 19620 & 592 & 14425 & 463 & 31.16 \\
\hline & $\mathrm{L} 17 / 2$ & 700 & 256 & 6 & 55 & 48 & 134 & 15 & 31 & 0 & 12 & 114 & 28544 & 678 & 2 & 2588 & 5647 & 236 & 3794 & 163 & 23.28 \\
\hline & L18 & 477 & 123 & 10 & 30 & 40 & 66 & 4 & 42 & 0 & 2779 & 131 & 32036 & 536 & 2 & 6051 & 10302 & 227 & 4643 & 216 & 21.50 \\
\hline & L19/2 & 646 & 134 & 21 & 45 & 47 & 337 & 14 & 32 & 32 & 27 & 25 & 19023 & 539 & 2 & 434 & 1041 & 113 & 776 & 66 & 11.75 \\
\hline & L19/3 & 410 & 152 & 19 & 40 & 33 & 164 & 23 & 27 & 3 & 62 & 100 & 17773 & 418 & 194 & 1708 & 3919 & 196 & 2835 & 136 & 20.85 \\
\hline & L19/4 & 539 & 167 & 27 & 43 & 41 & 163 & 21 & 38 & 0 & 16 & 104 & 27074 & 576 & 2 & 1687 & 3893 & 223 & 2852 & 141 & 20.27 \\
\hline
\end{tabular}


However, the thickness of the soil overburden, vegetation cover, and rainfall shield the gamma radiation, and it is estimated that $2 \mathrm{~cm}$ of soil cover reduces the radiation by 35 percent (Minty, 1997a). Also, a 10 percent increase in soil moisture decreases the radiation flux from the surface by about the same amount (Minty, 1997b) and it elucidates the reported lower GDR values for swampy or paddy areas of the study area.

The reported radioactive anomalies are caused by the occurrence of radioactive minerals consisting of terrestrial radionuclides viz. $\mathrm{Th}, \mathrm{U}$, and $\mathrm{K}$ in their structure, in higher concentrations. According to the mineralogical analysis, monazite is the main Th bearing radioactive mineral encountered in all of the locations. As a result of its higher density and resistance to chemical and physical weathering, monazite is able to survive during the transportation from a distant bedrock source to its deposition in a stream, river, or coastal environment (IAEA, 2019b). A potential $U$ mineralization or $U$ bearing primary or secondary minerals were not recorded during the study, and the reported $\mathrm{U}$ content may have incorporated into monazite and zircon. Surprisingly, a notable uranium occurrence, entirely based on the radiological data has been recorded at Kurudugahahetekma (L02) anomaly, conversely, the chemical and mineralogical data cannot uphold any $U$ enrichment within the area. However, the lowest recorded $\mathrm{Th} / \mathrm{U}$ ratio at L02 may indicate $\mathrm{U}$ mineralization rather than $\mathrm{Th}$, and further investigations are needed to confirm it. Compared to $\mathrm{Th}$ or $\mathrm{U}$ series, K (K-40; constituting $0.012 \%$ of $\mathrm{K}$ ) is a much weaker source of radiation. Nevertheless, due to its higher abundance (2\%), it is found to be an equal contributor as $\mathrm{U}$ and $\mathrm{Th}$ in the natural radiation flux (Minty, 1997a, b; Dickson and Scott, 1997; Dhana Raju, 2005). K is largely combined in feldspar and mica minerals, however due to the weathering process; $\mathrm{K}$ is eventually concentrated in the clay minerals. According to the mineralogy, most of the heavy minerals in beaches/raised beach deposits were not accumulated with such minerals and it explicated the lower nuclide specific dose rate value of $\mathrm{K}(3-5 \mathrm{nSv} / \mathrm{h})$ in beaches/raised beach deposits than inland anomalous areas $(>10 \mathrm{nSv} / \mathrm{h})$. In addition, field GDR data revealed that most of the areas with
GDR values $100-150 \mathrm{nSv} / \mathrm{h}$ are due to the $\mathrm{K}$ concentration rather than the $\mathrm{Th}$ or $\mathrm{U}$ concentrations.

Collaborative interpretation of field and radiological data has revealed that anomalies in Group III locations are due to radioactive elements enriched pegmatite bodies (several ten to hundred meters long) or placer deposits. Some of the inland locations of Group III are associated with calc-gneisses. This type of calc-silicate rocks and accompanying radioactive mineral deposits have been reported in the world such as in Australia and Canada (Hoaston et al., 2011) and it may indicate a link between their origin. Anomalous radioactivity reported in Group II is due to the existence of mainly Th enriched small scale pegmatites (few meters long) or placer deposits, and Group I is due to the ${ }^{40} \mathrm{~K}$ enrichment or mainly Th slightly enriched gneisses/placer deposits. Moreover, Group I and Group II may comprise a fairly enriched concentration of radioactive elements and it may suggest that the potential reserve of radioactive minerals is still not exposed, but existing below the ground (e.g. Thorianite occurrence at Maddegama).

The elemental concentration values for each location (anomalies) are normalized with the average upper continental crustal values (AUCC) presented by Taylor and McLennan (1985) and the Enrichment Factor (EF) for each element is then calculated to describe the enrichment of major and trace elements compared to average upper crustal abundance (Chandrajith et al., 2001a) (Figure 6, 7). According to the plotting of EF of alkali/ alkali earth metals and transitional elements against the anomalies, does not show a significant variation pattern except for $\mathrm{Ti}$ and it may be due to the mobilization of most of these elements in different scale during weathering (Figure $6 \mathrm{a}, \mathrm{b}, \mathrm{c}$ and $\mathrm{d}$ ). The concentration of $\mathrm{P}$ shows a positive anomaly particularly for beach samples and few inland samples indicating the relatively higher abundance of $\mathrm{P}$ ( $\mathrm{EF}=$ up to 24) bearing minerals such as monazite (Figure $7 \mathrm{a}, \mathrm{b}$ ). The elements categorized into the HFSE group, notably $\mathrm{Y}, \mathrm{Nb}, \mathrm{Zr}$, Th, U, La, and $\mathrm{Ce}$, have shown a characteristic variation with the radioactive anomalies than other elemental groups. According to the analyzed data, a significant enrichment of Th can be observed 
in the inland and beach/raised beach samples with a higher EF (28 to 1400 for Th) (Figure $7 \mathrm{c}$, d). However, U does not show higher enrichment at most of the anomalous areas compared to $\mathrm{Th}$ (recorded average $\mathrm{Th} / \mathrm{U}$ ratio is 32.99). In addition, many of the anomalous areas under Group III have shown a high abundance of some of the other HFSE (e.g. Zr, $\mathrm{La}, \mathrm{Ce}$ ) and follow the concentration pattern of radioactive elements ( $\mathrm{Th}$ and $\mathrm{U}$ ). It endorses the fact that the Th and $\mathrm{U}$ occur together with 'Rare Metals' (Niobium (Nb), Tantalum (Ta), Beryllium (Be), Lithium (Li), etc.) and REEs due to comparable chemical properties such as ionic radius, ionic charge, electronegativity, etc. (Dhana Raju, 2005). La and Ce (LREE) are highly enriched in most of the locations and records the highest EF of 407 and 445 respectively for the anomaly at L05. The concentrations of Th, U, and LREE increase with the increasing $\mathrm{P}$ content showing similar variation pattern at each locality (Figure 8a).
Moreover, Th, U, and LREE (La and Ce) show a more or less linear relationship with monazite content of the inland and beach/raised beach anomalies indicating the primary source of the these HFSE are from monazite. $\mathrm{Zr}$ is found in most of the coastal samples with elevated concentrations and shows the highest EF of 291 at L16 (Figure 7c, d). According to the mineralogy main zirconium bearing mineral found was zircon, and is heavily concentrated in beach/raised beach areas, and rock pieces at Baddegama. Although, Yttrium (Y) does not show any relative enrichment at most of the inland and beach/raised beach localities (EF - 0.6 to 20) (Figure 7c, d), the field GDR data at most of the anomalous areas have shown anomalous $\mathrm{Y}$ nuclide specific dose rate values (up to 182 $\mathrm{nSv} / \mathrm{h}$ ). Contrary to the expectations, $\mathrm{Nb}$ does not show a higher EF for most of the anomalies. However, their content increases with the Ti content (Table 3 and 4, Figure 8b).
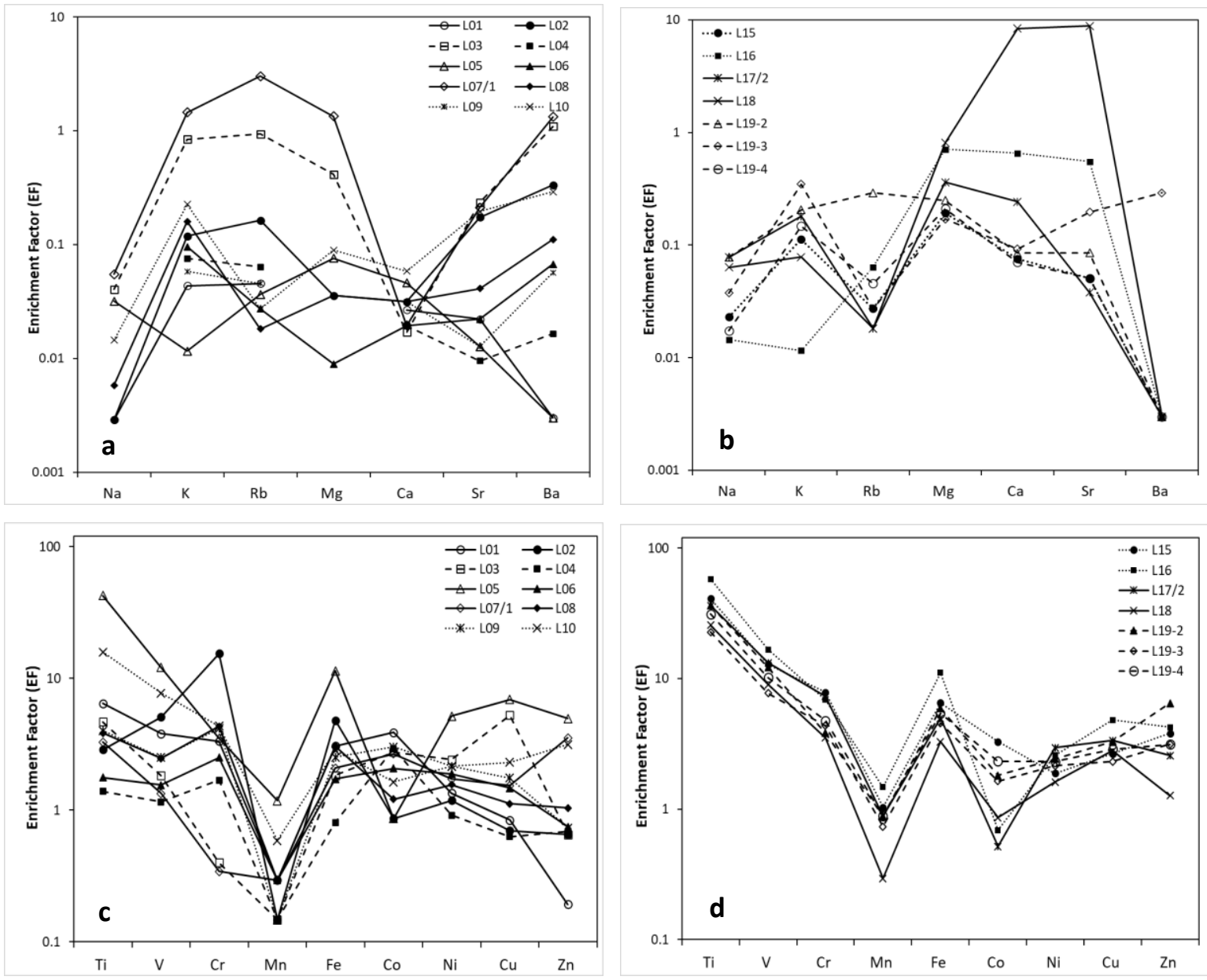

Fig. 06. The variation of enrichment factors of; (a) alkali and alkali earth elements group of inland, (b) alkali and alkali earth elements group of beach/raised beach, (c) transition group elements group of inland, and $(d)$ transition group elements group of beach/raised beach, locations. 

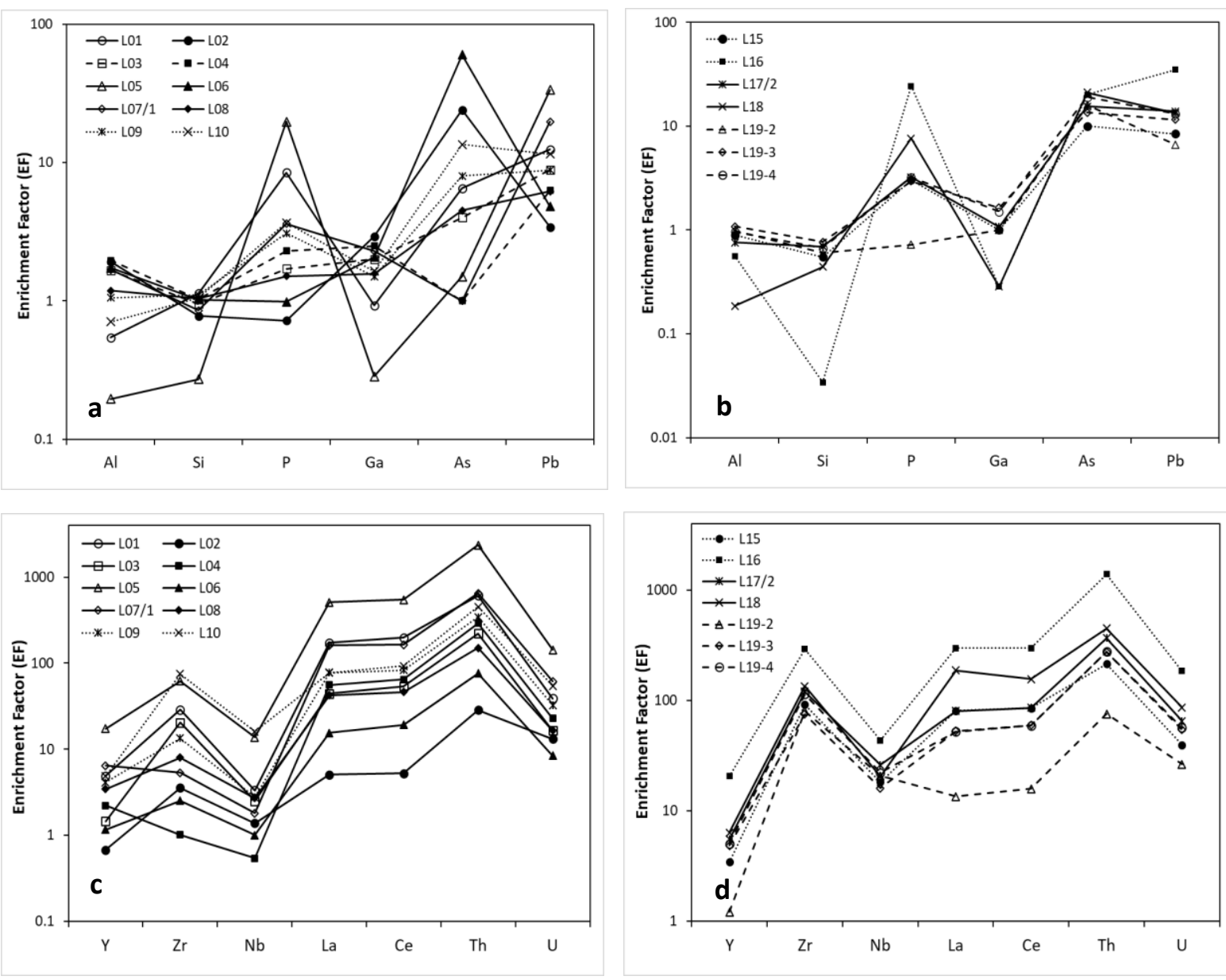

Fig. 07. The variation of enrichment factors of; (a) other elements group (Al, Si, As, $P$, Ga and Pb) of inland, (b) other elements group of beach/raised beach, (c) high field strength elements group of inland, and $(d)$ high field strength elements group of beach/raised beach, locations.

This indicates either the presence of niobium rutile in the heavy mineral concentrate in the southwestern region of Sri Lanka, as it also formerly recorded in the elsewhere of Sri Lanka (Chandrajith et al., 2001b; Rupasinghe et al., 1983) or niobium incorporated ilmenite.

Th and associated HFSE are originated through different processes and enriched in different rock types, and accumulated in secondary placer deposits in the world. Primary deposits of such Th and HFSE are found in alkaline/peralkaline and associated igneous rocks (veins/pegmatites), syenites and related rocks, carbonatite, charnockite leucotonalite dykes and high-grade metasomatites. During the present study or previous petrological studies on the southwestern part of Sri Lanka, any evidence of the occurrence of carbonatite rocks or alkaline/peralkaline-rich igneous suite was not encountered (Prame and Pohl, 1994). On the other hand, monazite bearing more felsic granitic pegmatites and associated gneisses were observed in this study. Prior studies have noted that monazite bearing pegmatites of the country often consist of mica (Searle, 1963) and this type of pegmatitic melts may have originated from granitic or igneous bodies or metamorphic fluids. According to the combined data from the published geological sheet No. 19 and field, many of the identified anomalous areas and identified pegmatites appear to be associated with the shear zones, faults or major lineaments of the area. Some of the pegmatitic veins showing crosscutting relationships with well-fitted adjacent rockwalls suggested the formation of the pegmatite along brittle tensile cracks (Fernando et al., 2011) and also reveal the post-peak metamorphic origin of them. However, further detailed works are needed to unravel the origin of these Th and LREE rich pegmatites. 

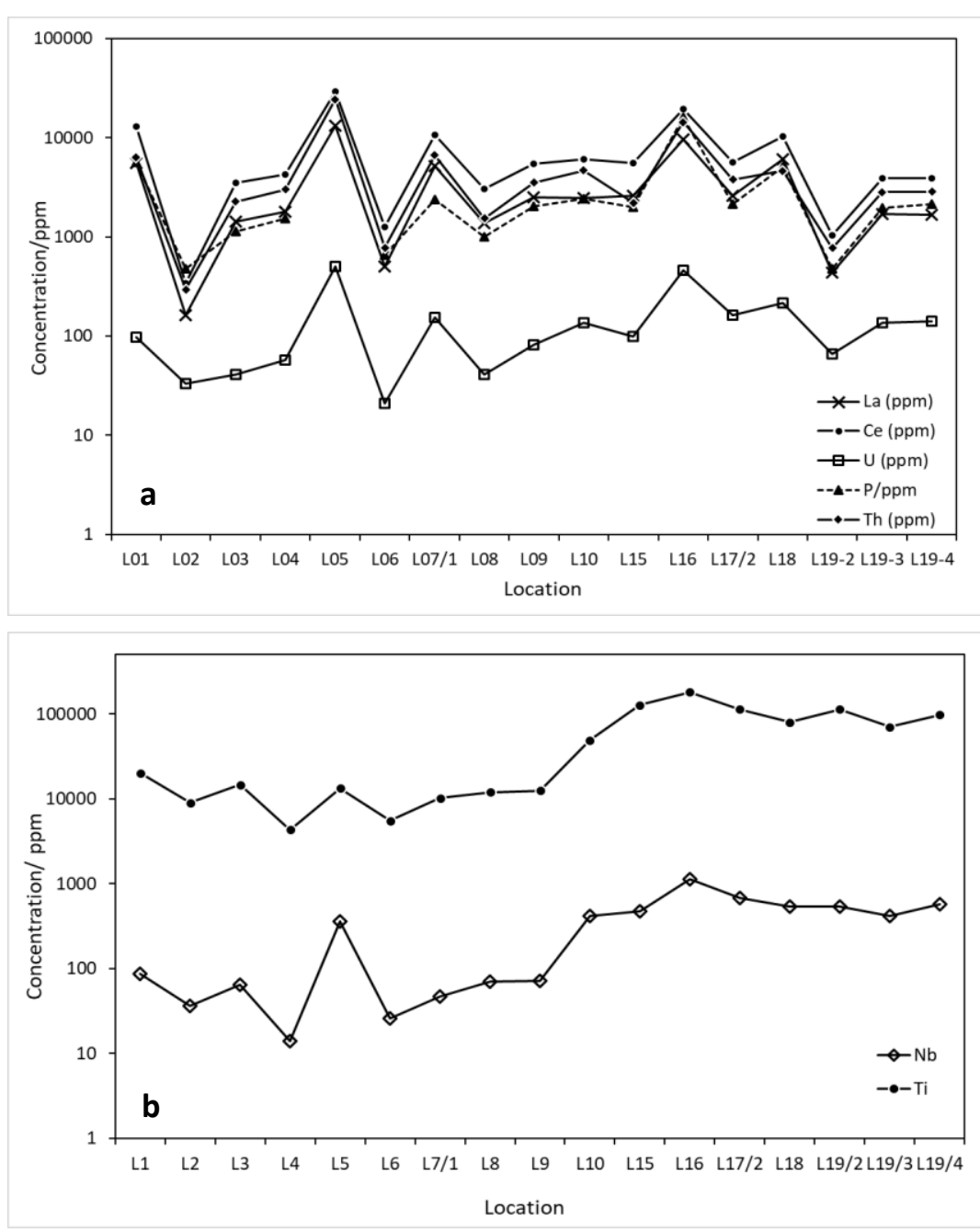

Fig. 08. Distribution patterns of (a) $P, T h, U, L a$, and Ce concentrations, (b) Nb and Ti concentrations with the locations.

Regarding the origin of Th and associated REE deposits in southwestern coastal areas, several hypotheses have been suggested; Rupasinghe et al. (1983) postulated that the Th rich monazite has been derived from a variety of gneisses and granitoid rocks in the southwestern part and Searle (1963) also recorded the occurrence of monazite bearing augen gneisses from Galle to Tangalle. However, field GDR data along with geological, mineralogical and geochemical data confirm the occurrence of small to large scale felsic pegmatite bodies with enriched monazite (Th and REEbearing). It can be hypothesized that this type of pegmatites will contribute a major proportion along with associated gneisses to the origin of monazite rich placer deposits in the southwestern coast of Sri Lanka.

Extensive radioactive mineral-bearing inland pegmatite deposits (>200 m length) have been located at Uragahasmanhandiya (L01), Pituwala (L03) and Makubura (L07), and minor scale inland radioactive mineral deposits with unconfirmed field origin have been identified at Yakkalamulla (L09), Kurudugaha (L02) and Idigahawila (L04). Mineralogical and chemical data on each location, especially the beach/ raised beach localities have revealed the elevated concentrations of monazite as well as $\mathrm{Th}, \mathrm{Ce}$, and $\mathrm{La}$ (up to $12 \%$ of monazite). The grade of Th of the most economic Th/REE primary deposits in the world estimated from $0.03 \%$ or greater and in India $>2 \%$ of total heavy minerals consisting of beach sand is considered for exploration purposes (IAEA, 2019a). Therefore, identified anomalous locations in the study area can be further examined for commercial extraction of $\mathrm{Th}$ and LREE ( $\mathrm{La}, \mathrm{Ce}$, etc.). However, Th still has minimal commercial applications and also a 
market for Th has not yet been developed. Even though Th cannot solely power a nuclear reactor as natural Uranium, it appears to be one of the most promising alternative fuel for power generation (Unak, 2000; Clery, 2005; Chalmers, 2010; Hargraves and Moir, 2010) and some Th breeder reactors have already been developed (Bagla, 2005; Uhlir, 2007). Under the current economic situation, recovery of Th as a byproduct of REE production from monazite is the most realistic option as the increment of REE prices recently (IAEA, 2019b). Therefore, exploration of monazite deposits in the country is vital and this type of radiometric survey is a tool for that.

The presented radiological data represent the highest values recorded during the radiometric survey. To acquire more generalized data, possibly for economic evaluation, systematic sampling and detailed mineralogical, and geochemical analysis should be conducted covering surrounding areas from the recorded anomalies. Moreover, to understand the economic potential of the identified localities, it is needed to assess the lateral and vertical distribution of the deposits and their mineralization.

\section{CONCLUSIONS}

The typical ground dose rate (GDR) for Aluthgama-Galle geological sheet area varies between $50-80 \mathrm{nSv} / \mathrm{h}$ and the average nuclide specific background GDR for Th, U, and $\mathrm{K}$ are recorded as $6 \mathrm{nSv} / \mathrm{h}, 5 \mathrm{nSv} / \mathrm{h}$ and $3 \mathrm{nSv} / \mathrm{h}$ respectively. The reported average GDR for the charnockitic terrain is $50-70 \mathrm{nSv} / \mathrm{h}$ whereas GDR of $70-80 \mathrm{nSv} / \mathrm{h}$ is recorded for garnetbearing gneissic terrains, and it confirms the existence of a strong correlation between natural radioactivity with the local geology within the study area. Based on the recorded GDR values for various terrains, $100 \mathrm{nSv} / \mathrm{h}$ was defined as the base value of the radioactive anomalies and reported anomalous locations were subdivided into three groups primarily based on the GDR values and the associated geology as; Group I: 100-300 nSv/h, Group II: 300-600 nSv/h and Group III: above $600 \mathrm{nSv} / \mathrm{h}$ (14 inland and, 5 beach/raised beach locations). The highest GDR value is recorded at the Uragasmanhandiya (L01) with a GDR value of $2300 \mathrm{nSv} / \mathrm{h}(\mathrm{Th}-432 \mathrm{nSv} / \mathrm{h}, \mathrm{U}-141 \mathrm{nSv} / \mathrm{h}$, and
$\mathrm{K}$ - $49 \mathrm{nSv} / \mathrm{h}$ ). Inland radioactive anomalies of Group III (e.g. Uragasmanhandiya, Pituwala, Makubura, etc.) are associated with pegmatite occurrences and the characteristic mineralogy of pegmatites is quartz + feldspar + monazite + zircon \pm biotite \pm garnet \pm ilmenite. Many of the anomalous areas with GDR value 100 - 150 $\mathrm{nSv} / \mathrm{h}$ are caused by the high $\mathrm{K}$ concentration rather than the $\mathrm{Th}$ or $\mathrm{U}$. The average $\mathrm{Th} / \mathrm{U}$ ratio is 32.99 for Group III $(\mathrm{Th} / \mathrm{U}$ ratio for inland samples is 44.54 and for beach/raised beach samples is 21.59) and confirms the higher abundance of Th than $U$ for the terrain. Higher enrichment factors (EF) compared to the average upper crust are reported for HFSE especially for Th, La, Ce, and $\mathrm{Zr}$ (e.g. 28 - 1400 for Th, 5 - 407 for La, 5 - 445 for Ce and 1 291 for Zr). The combined analysis of radiology, mineralogy, and geochemistry shows that the radioactive anomalies mainly depend on the monazite content of the location, and monazite serve as the main source for the high concentration of Th, La, and Ce. Most of the radioactive anomalous areas and pegmatites are associated with the major shear zones and major lineaments within the area suggesting a structurally influenced radioactive mineralization. The results of the analysis show that the main cause for the monazite placer deposits at the southwestern coastal region is the monazite-rich granitic pegmatites and associated gneisses of the region. Moreover, systematic mineralogical, geochemical, and radiological studies are needed to evaluate the radioactive mineral deposits, their extent, and the economic potential.

\section{ACKNOWLEDGMENTS}

The authors wish to acknowledge Dr. W. K. B. N. Prame, Geol. M. M. J. P. Ajith Prema, Ms. Y. P. S. Siriwardana, Mr. D. M. S. Dissanayake, Mr. A. A. Chinthaka Priyantha, Ms. Upeksha Diddeniya, and Ms. Nisansala Ganegama of Geological Survey and Mines Bureau for their kind assistance in laboratory works and manuscript preparation. Further, we would like to extend our appreciation to the Geological Survey and Mines Bureau for providing financial support for this research Authors gratefully acknowledge the equipment and training support by International Atomic Energy Agency (IAEA) under Technical Cooperation Project SRL 2009. 


\section{REFERENCES}

Abeysinghe, P.B. (1985) Uranium anomalies in the Kala Oya area and study of the associated granites. Unpublished report. Geological Survey Department, Sri Lanka, $30 \mathrm{pp}$.

Abeysinghe, P.B. and Fernando, M.R.D. (1986) Uranium mineralization in Sri Lanka. L.J.D. Fernando Felicitation volume. Journal of the Geological Society of Sri Lanka, 45-57.

Anderson, B.W., Claringbull, G.F., Davis, R.J. and Hill, D.K. (1961) Ekanite, a new metamict mineral from Ceylon. Nature, 192 (4780): 997-997.

Bagla, P. (2005) Rethinking nuclear power: India's homegrown thorium reactor. Science, 309 (5738): 1174-1175.

Chalmers, M. (2010) Enter the thorium tiger. Physics World, October 2010: 40-46.

Chandrajith, R., Dissanayake, C.B and Tobschall, H.J. (2001a) Application of multi-element relationships in stream sediments to mineral exploration: a case study of Walawe Ganga Basin, Sri Lanka. Applied Geochemistry, 16: 339-350.

Chandrajith, R., Dissanayake, C.B and Tobschall, H.J. (2001b) Enrichment of high field strength elements in stream sediments of a granulite terrain in Sri Lanka - evidence for a mineralized belt. Chemical Geology, 175: 259-271.

Clery, D. (2005) Nuclear industry dares to dream of a new dawn. Science, 309 (5738): 1172-1175.

Coomaraswamy, A.K. (1903) Mineral Survey of Ceylon. Administrative Report. Department of Mineralogical Survey, Ceylon, 10 pp.

Coomaraswamy, A.K. (1904a) Report on Thorianite and Thorite. Government Printing Office, Colombo. 21 pp.

Coomaraswamy, A.K. (1904b) Uraninite. Spolia Zeylanica 6 (2): 57.

Coomaraswamy, A.K. (1905) Mineral Survey of Ceylon. Administrative Report. Part IV, $18 \mathrm{pp}$.

Coomaraswamy, A.K. (1906) Mineral Survey of Ceylon. Administrative Report. Part IV, $11 \mathrm{pp}$.

Cooray, P.G. (1965) Geology of the country around Aluthgama. Ceylon Geological Survey (Department of Mineralogy), 3.
Cooray, P.G. (1994) The Precambrian of Sri Lanka: a historical review. Precambrian Research, 66: 3-18.

Dhana Raju, R. (2005) Radioactive Minerals. Geological Society of India, Bangalore, 65 pp.

Dickson, B.L. and Scott, K.M. (1997) Interpretation of aerial gamma-ray surveys-adding the geochemical factors. Journal of Australian Geology and Geophysics, 17(2): 181-200.

Dunstan, W. R. (1904) The occurrence of thorium in Ceylon. Nature, 69 (March 31): 510-511.

Dunstan, W. R. and Blake, A.R.S.M. (1905) Thorianite, a new mineral from Ceylon. Proceedings of the Royal Society of London, 76 (88): 510-533.

Faulhaber, D.W. and Raith, M. (1991) Geothermometry and geobarometry of high-grade rocks: a case study on garnet pyroxene granulite in southern Sri Lanka. Mineralogical Magazine, 55: 17-40.

Fernando, G. W. A. R., Pitawala, A. and Amaraweera, T. H. N. G. (2011) Emplacement and evolution history of pegmatites and hydrothermal deposits, Matale district, Sri Lanka. International Journal of Geosciences, 2: 348-362.

Fletcher, L. (1893) On baddeleyite, new mineral from Rakwana, Ceylon. Mineralogical Magazine, 54(6): 160-166.

Geological Map of Aluthgama - Galle (Sheet No. 19), 1:100 000 scale, published by Geological Survey and Mines Bureau, 2000.

Haldar, S.K. (2013) Exploration Geophysics, Mineral Exploration: Principles and Applications. Elsevier, (2 ${ }^{\text {nd }}$ ed.), pp 73-93.

Hapuarachchi, D.J.A.C. (1969) Geological map (advanced copy) and explanation of the Geology.

Hargraves, R. and Moir, N. (2010) Liquid thorium reactors. American Scientist, 98 (July-August): 304-313.

Hoatson, D.M., Jaireth, S. and Miezitis, Y. (2011) The major rare-earth-element deposits of Australia: geological setting, exploration, and resources. Geoscience Australia, $204 \mathrm{pp}$.

Hood, H.J. (1959) Report on the Maddegama radioactive survey for the radioactive minerals thorianite. The Photographic survey cooperation limited, Toronto, Canada. 30 pp. 
IAEA (2003) Guidelines for radioelement mapping using gamma ray spectrometry data. International Atomic Energy Agency. IAEA-TECDOC-1363, $152 \mathrm{pp}$.

IAEA (2019a) World thorium occurrence deposits and resources. International Atomic Energy Agency. IAEA-TECDOC- 1877, 1-38. Journal of National Science Council Sri Lanka, 11 (1): 99-110.

IAEA (2019b) Thorium resources as co- and byproducts of rare earth deposits. International Atomic Energy Agency. IAEA-TECDOC-1892, 38 pp.

Jayawardane, D.E.de.S. (1986) History of the Geological Survey 1903 - 1985. L.J.D. Fernando Felicitation volume. Journal of the Geological Society of Sri Lanka, 15-32.

Killeen, P.G. and Cameron, G.W. (1977) Computation of in situ potassium, uranium, and thorium concentrations from portable gamma-ray spectrometer data. In report of activities, part A. Geological Survey of Canada, 77-A: 91-92.

Killeen, P.G., Mwenifumbo, C.J. and Ford, K.L. (2015) Tools and Techniques: Radiometric Methods, Treatise on Geophysics ( $2^{\text {nd }}$ ed.). Elsevier, 447-524.

Kröner, A., Cooray, P.G. and Vithanage, P.W. (1991) Lithotectonic subdivision of the Precambrian basement in Sri Lanka. In: Kröner, A (ed.) The Crystalline Crust of Sri Lanka, Professional Paper 5, Geological Survey Department, Sri Lanka, pp 5-21.

Lentz, D. (1991) Radioelement distribution in U, Th, Mo, and rare-earth-element pegmatites, skarns, and veins in a portion of the Grenville Province, Ontario and Quebec. Canadian Journal of Earth Sciences, 28: 1-12.

Milisenda, C.C., Liew, T.C., Hofmann, A.W. and Kröner, A. (1988) Isotopic mapping of age provinces in Precambrian high-grade terrains: Sri Lanka. Journal of Geology, 96: 608-615.

Minty, B.R.S. (1997a) Fundamentals of airborne gamma-ray spectrometry. Journal of Australian Geology and Geophysics, 17(2): 39-50.

Minty, B.R.S. (1997b) Calibration and data processing for airborne gamma-ray spectrometry. Journal of Australian Geology and Geophysics, 17 (2): 51-62.
Prame, W.K.B.N. and Pohl, J. (1994) Geochemistry of pelitic and psammopelitic Precambrian metasediments from southwestern Sri Lanka: implications for two contrasting source-terrains and tectonic settings. Precambrian Research, 6: 223-244.

Rupasinghe, M.S., Gocht, W. and Dissanayake, C.B. (1983) The genesis of thoriumrich monazite placer deposits in Sri Lanka. Journal of National Science Council Sri Lanka, 11 (1): 99-110.

Sameera, K.A.G. and Perera, L.R.K. (2015) Petrological study of calc-silicate granulites in the Southern Highland Complex of Sri Lanka. Journal of the Geological Society of Sri Lanka, 17: 87-100.

Sameera, K.A.G., Fernando, G.W.A.R. and Dharmapriya, P.L. (2020a) First report on insitu occurrences of ekanite from Galle, South-western Highland Complex, Sri Lanka. Proceedings of the $36^{\text {th }}$ Annual Technical Sessions of Geological Society of Sri Lanka, pp 3.

Sameera, K.A.G., de Silva, K.T.U.S., Welikanna, C.R., Harankahawa, S.B. and Wickramasinghe, W.A.G.K. (2020b) Carborne radiometric mapping and recently identified radioactive anomalous zones in the south-western, Sri Lanka. Proceedings of the $36^{\text {th }}$ Annual Technical Sessions of Geological Society of Sri Lanka, pp 16.

Searle, D.L. (1962a) A geological report on the radiometric mineral occurrences in the Aluthgama area with special references to the beach sands, Unpublished report. Geological Survey of Ceylon, $36 \mathrm{pp}$.

Searle, D.L. (1962b) Hydrothorite, zircon, hydrated allanite and uraniferous leucoxene from a pegmatite near Balangoda. Unpublished report. Geological Survey of Ceylon. 10 pp.

Searle, D.L. (1962c) Summary of the radiometric traverses in the Galle and Matara map sheet area. $20 \mathrm{pp}$.

Searle, D.L. (1963) Prospecting for radioactive minerals in Ceylon, International Atomic Energy Agency (IAEA). Report WP/5/86. Unpublished report. Report to the Government of Ceylon. 19 pp.

Taylor, S.R. and McLennan, S.M. (1985) The continental crust: Its composition and evolution. Blackwell, Oxford. An examination of the geochemical record preserved in sedimentary rocks. pp 320. 
Taylor, S.R. and McLennan, S.M. (1995) The geochemical evolution of the continental crust. Reviews of Geophysics, 33: 241-265.

Tennakone, K. (2011) Thorium minerals in Sri Lanka, history of radioactivity and thorium as a future energy source: a compendium to commemorate the International Year of Chemistry 2011. Journal of Natural Science Foundation Sri Lanka, 39 (2): 97-111.

Uhlir, J. (2007) Chemistry and technology of molten salt reactors-history and perspectives. Journal of Nuclear Materials, 360 (1): 6-11.

Unak, T. (2000) What is the potential of the use of thorium for energy production? Progress in Nuclear Energy, 37(14): 137-144.

Vosniakos, F., Zavalaris, K., Papaligas, T., Aladjadjiyan, A and Ivanova, D. (2002) Measurements of natural radioactivity concentration of building material in Greece, Journal of Environmental protection and Ecology, 3: 24-29.

Wadia D.N. and Fernando L.J.D. (1946) Ilmenite, monazite, zircon and gems and semi-precious stones. Geological Magazine, 83(2): 200-232.

Yasir, M.S., Majid, A. and Yahaya, R. (2007) Study of natural radionuclides and radiation hazard index in Malaysia building Its material. Journal of Radioanalytical and Nuclear Chemistry, 273: 539-541.

Yeboah, J., Boadu, M. and Darko, E. O. (2001) Natural radioactivity in soils and rocks within the Greater Accra region of Ghana. Journal of Radioanalytical and Nuclear Chemistry, 249 (3): 629-632. 